\title{
A mechanistic study on the inhibition of bacterial growth and inflammation by Nerium oleander extract with comprehensive in vivo safety profile
}

Yousra Shafiq ${ }^{1}$, Syed Baqir Shyum Naqvi², Ghazala H. Rizwani ${ }^{3}$, Muhammad Arif Asghar ${ }^{1 *}$ (D, Rabia Bushra ${ }^{4}$, Sana Ghayas ${ }^{4}$, Ahad Abdul Rehman ${ }^{5}$ and Muhammad Asif Asghar ${ }^{6}$

\begin{abstract}
Background: Nerium oleander (L.) is well known traditionally used medicinal plant with several pharmacological activities. However, the anti-bacterial, anti-inflammatory activity and in vivo toxicity potential of floral parts of this plant are not reported. Therefore the present study was designed to investigate these activities of Nerium oleander ethanolic flower extract (NOEE) in different animal models.

Methods: Antimicrobial activity of plant extract was compared with five different antibiotics using the disk diffusion method. The time-killing kinetic assay and bacterial killing mechanism of NOEE were also performed. Anti-inflammatory activity was assessed using granuloma induced by cotton-pellet, rat paw edema induced by carrageenan and levels of different inflammatory biomarkers on healthy Wistar rats. The protein and mRNA expressions of nitric oxide (NO), prostaglandin $E_{2}\left(P G E_{2}\right)$, tumor necrosis factor-a (TNF-a) and interleukin-1 $\beta$ (IL-1 $\left.\beta\right)$ were also measured. Acute (14 days) and sub-acute (28 days) oral toxicity studies were also performed on healthy Sprague Dawley rats.

Results: NOEE produced highly significant $(P<0.005)$ and significant $(P<0.05)$ zones of inhibition at $30 \mathrm{mg} / \mathrm{mL}$ and $20 \mathrm{mg} / \mathrm{mL}$ respectively against most of the tested bacterial strains. NOEE produced a more drop in viable counts of Gram-negative isolates within $20 \mathrm{~min}$. After $12 \mathrm{~h}$ exposure with NOEE, the SEM images of MRSA showed the destruction of cell membrane. NOEE showed highly significant $(P<0.005)$ anti-inflammatory activity in cotton-pellet and carrageenan inflammatory models. In addition, treatment with NOEE also decreased the production of $N O, P G E_{2}, T N F-a$ and $I L-1 \beta$ in the rat paw after treated with carrageenan. Similarly, NOEE also suppressed the inducible nitric oxide synthase (iNOS), TNF-a, IL-1 $\beta$, and cyclooxygenase-2 (COX-2) mRNA expressions. It is also showed highly significant reduction in total leukocyte count (73.09\%) and C-reactive protein levels (54.60\%). NOEE also inhibited COX-1, COX-2, 5-LO and 12-LO in a highly significant manner. Moreover, acute and sub-acute toxicity studies of NOEE in rats confirm the toxicity with hepatotoxicity at higher doses $(2000 \mathrm{mg} / \mathrm{kg})$ i.e. four times greater than the therapeutic dose.

(Continued on next page)
\end{abstract}

* Correspondence: m.arifasgher@hotmail.com

${ }^{1}$ Department of Pharmaceutics, Institute of Pharmaceutical Sciences, Jinnah Sindh Medical University, Rafiqui H. J Shaheed Road, Karachi 75510, Pakistan

Full list of author information is available at the end of the article

(c) The Author(s). 2021 Open Access This article is licensed under a Creative Commons Attribution 4.0 International License, which permits use, sharing, adaptation, distribution and reproduction in any medium or format, as long as you give appropriate credit to the original author(s) and the source, provide a link to the Creative Commons licence, and indicate if changes were made. The images or other third party material in this article are included in the article's Creative Commons licence, unless indicated otherwise in a credit line to the material. If material is not included in the article's Creative Commons licence and your intended use is not permitted by statutory regulation or exceeds the permitted use, you will need to obtain permission directly from the copyright holder. To view a copy of this licence, visit http://creativecommons.org/licenses/by/4.0/ The Creative Commons Public Domain Dedication waiver (http://creativecommons.org/publicdomain/zero/1.0/) applies to the data made available in this article, unless otherwise stated in a credit line to the data. 
(Continued from previous page)

Conclusion: It is concluded that crude flower extract of $N$. oleander is a potent antimicrobial and antiinflammatory agent with no toxicity potential at therapeutic doses.

Keywords: Nerium oleander, Time killing kinetics, Anti-inflammatory activity, Acute and sub-acute toxicity

\section{Background}

In order to balance the host defense against pathogenic threats, an inflammatory response is required. Though, uncontrollable eicosanoid production is usually associated with multiple chronic inflammatory diseases [1]. It has been reported in different studies that mostly inflammation is initiated by the injury of living cells either by the outbreak of microorganisms, poor or weak immune response and sometimes by physical agents [2]. However, the fundamental response of inflammation is considered to be a protective response by eradicating the initial cause of cell injury, following the start of the cell repair process [3]. The numbers of anti-inflammatory mediators are responsible for inflammation resolution along with monocyte recruitment for the deletion of tissue debris or cell. Chronic inflammation usually causes burden in terms of pathological conditions in both developing and under-developing countries [4].

There are numbers of drugs available in the market to treat and control inflammatory distress including NSAI Ds, steroids and immune suppressants while such medications are also associated with multiple adverse effects [5]. So, the present approach of study is to investigate a drug candidate with minimum side effects and maximum efficacy from the green world. In recent years, various researchers have focused on natural products that are derived from medicinal plants i.e. flavonoids, alkaloids, polyphenols, steroids, coumarins and terpenes because of their broad range of pharmacological importance [6-9]. Recently, the World Health Organization (WHO) reported that around $80 \%$ of the human population utilized herbal medicines for the management of some aspects of primary health care [10].

Nerium oleander belongs to the family Apocynaceae, is an evergreen shrub and is found widely distributed throughout the world [11]. The image of the plant along with its flowers is also given in Fig. 1. Plant was reported for its antibacterial [12], antifungal [13], antidiabetic [14], antioxidant [15], antitumor [16] and hepatoprotective activities [17]. Phyto-constituents such as flavonoids, triterpenes, anthraquinones, coumarins, cardiac glycosides like oleandrin and nerine have been reported in this plant [18].

It has been reported that plants containing a high proportion of flavonoids and saponins showed good analgesic and anti-inflammatory potentials while ethanolic extract of $N$. oleander also possessed a rich quantity of such phytochemical constituents responsible for these activities $[6,19]$. Moreover, various plants of the Apocynaceae family were evaluated for their anti-inflammatory activity in different animal models. Fruits extract of Hancornia speciosa showed remarkable anti-inflammatory activity against inflammatory induced animal models [20]. Saleem et al. evaluated the anti-inflammatory activity of Gendarussa vulgaris leaves against carrageenan-induced paw edema [21]. In addition, very few studies extract out regarding the anti-inflammatory activities of $N$. oleander with few inflammatory induced models.

Even though, the flowers of this plant are traditionally used topically in the treatment of inflammation due to bacterial infections particularly in rural areas of Pakistan. However, there is no scientific data reported on the comprehensive in vivo anti-inflammatory and antibacterial activity of $N$. oleander flowers. Also, investigation of the safety profile of this plant is highly required given the pervasive use. Thus, the present study was performed to assess the time killing antibacterial assay, anti-inflammatory and toxicity activities of $N$. oleander flowers extract at different doses in animal models.

\section{Methods}

\section{Collection and extraction of plant material}

Fresh flowers of Nerium oleander were purchased from a local herb research market of sadder town in KarachiPakistan in the month of June, a peak time for their growth. It was identified by the meritorious Professor and Pharmacognosist Prof. Dr. Ghazala H. Rizwani at Center of Plant Conversation, University of Karachi, Pakistan and the plant voucher specimen was deposited at the Center of Plant Conversation, University of Karachi, Pakistan with voucher specimen no. CE-0091. The collected flowers were washed, shade dried and course powdered by an electric grinder. The amount of $500 \mathrm{~g}$ dried powdered plant material was extracted using Soxhlet extractor with $1 \mathrm{~L}$ of $50 \%$ ethanol for $24 \mathrm{~h}$. Plant material was filtered and concentrated under reduced pressure using a rotary vacuum evaporator at $40{ }^{\circ} \mathrm{C}$ (IKA, Germany) [6]. The final product of Nerium oleander ethanolic extract (NOEE) was a blackish brown color mass with a $7.56 \%$ yield.

\section{Phytochemical screening}

Different phytochemical screening tests were performed in order to determine the phytochemical constituents in 


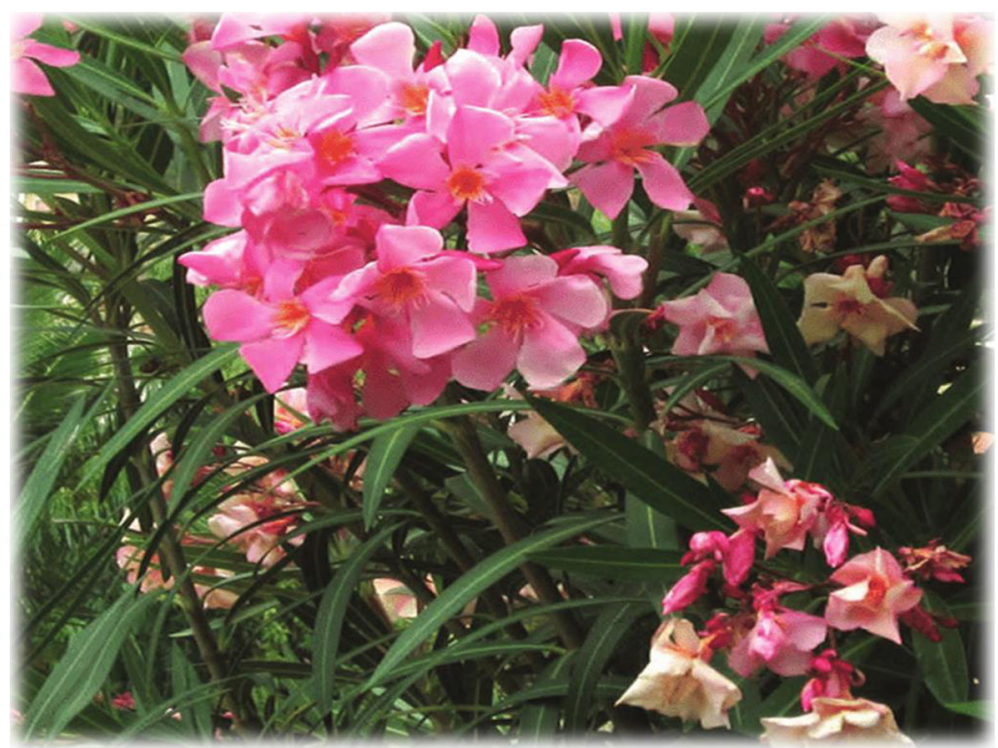

Fig. 1 Plant of Nerium oleander with its flowers

NOEE. Total flavonoids and cardiac glycosides in plant extract were estimated using Shinoda and Keller-Kiliani tests. Total phenolic contents in the extract were assessed using the ferric chloride test, whereas total alkaloids were determined using Mayer's reagent. Borntrager's and froth tests were used for the estimation of total anthraquinones and saponins levels respectively while total phytosterols were estimated using LiebermannBurchard test [22].

\section{Antibacterial susceptibility testing's}

Determination of zones of inhibitions (Zls)

Five different antibiotic discs of $10 \mu \mathrm{g} /$ disc concentrations were used as standard, namely amoxicillin, erythromycin, gentamycin, levofloxacin and tetracycline (OXOID, UK). Different clinical isolates including Bacillus subtilis (LT 0412), Escherichia coli (LT 0613), Klebsiella pneumonia (LT 0843), Pseudomonas aeruginosa (LT 0618), Methicillin-resistant Staphylococcus aureus (MRSA) (LT 0251), Staphylococcus aureus (LT 0871), Staphylococcus epidermidis (LT 0482), Salmonella enterica (LT 0305), Streptococcus fecalis (LT 0711), Streptococcus pyogenes (LT 0121) and Salmonella typhi (LT 0235) were obtained and identified by Pathologist from the pathological laboratory of Darul-Sehat Hospital Karachi Pakistan. These bacterial strains reported a highly resistant pattern in previous studies, particularly in Asian countries. Plant discs with $20 \mu \mathrm{L}$ extract solution $(6 \mathrm{~mm}$ in diameter) of different concentrations, i.e. $10,15,20$ and $30 \mathrm{mg} / \mathrm{mL}$ were used for the evaluation of its antibacterial activity using a Clinical Laboratory and Standard Institute (CLSI) approved disc diffusion method $[23,24]$. The bacterial culture was inoculated in sterile Muller Hinton agar (MHA) (Oxoid, Hemisphere, England) and incubated for $24 \mathrm{~h}$ at $37^{\circ} \mathrm{C}$. The 0.5 McFarland standard was used to achieve $10^{6}$ cell $/ \mathrm{mL}$ concentrations of each strain. Antibacterial discs were placed on the MHA plates and incubated for $24 \mathrm{~h}$ in an incubator (Thermo Fisher Scientific, USA) at $37^{\circ} \mathrm{C}$. Inhibition zones were measured using a digital Vernier caliper.

\section{Determination of minimum inhibitory concentration (MIC) and minimum bactericidal concentration (MBC)}

MICs and MBCs of NOEE against tested isolates were determined using the broth dilution method [25]. Briefly, the plant extract with a concentration of $50 \mathrm{mg} / \mathrm{mL}$ was prepared in a nutrient broth and make several dilutions up to $0.1 \mathrm{mg} / \mathrm{mL}$ using the serial dilution method. All tested bacterial strains were adjusted to the concentration of $1 \times 10^{6} \mathrm{cfu} / \mathrm{mL}$ as McFarland standard. After overnight incubation of inoculated microbial plates, optical densities (ODs) were measured using an ELISA reader (Infinite 200; USA) at $600 \mathrm{~nm}$. In addition, MBCs of plant extract was determined by spreading the solution of microbial strains on nutrient agar plates and incubated at $37^{\circ} \mathrm{C}$ for $24 \mathrm{~h}$. After an incubation period, bacterial colonies on each inoculated plate were observed [26, 27]. Each experiment was performed three times and mean $\pm \mathrm{SD}$ values of each test were reported.

\section{Killing kinetics assay}

The time-killing kinetics study on NOEE was performed according to the method defined in our previous study [28]. The bacterial cells were grown in logarithmic phase up to $8 \operatorname{logs} \mathrm{cfu} / \mathrm{mL}$ in nutrient broth then treated with 
plant extract in the concentration equal to obtained MBCs of each tested bacterial isolate. Bacterial culture was drawn after every $5 \mathrm{~min}$ and plated on Tyramide Signal Amplification (TSA) in order to measure the bacterial cell viability. The time-killing kinetic plot was constructed between the viability of bacterial isolates in Log $\mathrm{cfu} / \mathrm{mL}$ and time in $\mathrm{min}$.

\section{Effects of NOEE on bacterial cells morphology}

The morphological study of bacterial cells after exposure with NOEE at their MIC was performed according to the method described in our previous study using a scanning electron microscope (SEM) (Joel, Model no SEM-2364, Japan) [29]. SEM study was carried out on MRSA cells since it is the most common virulence bacteria for human and cause several infections including urinary tract infections, wounds infections and different systemic infections. Before and after 6 and $12 \mathrm{~h}$ treatment with NOEE, bacterial suspension was placed on filter membrane and dried for $2 \mathrm{~h}$. Then the bacterial culture was fixed with the solution of glutaraldehyde in $2.5 \%$ phosphate buffer. The bacterial isolate was stained for 60 min with $\mathrm{OsO}_{4}$ solution in $1 \%$ phosphate buffer and dehydrated with a hydroalcoholic mixture. Finally, the gold-coated filter membrane was analyzed.

\section{Evaluation of anti-inflammatory activity \\ Animals}

Sprague Dawley rats of both sexes were obtained from the animal house of the Pakistan Council of Scientific and Industrial Research (PCSIR), with an average body weight of $220-250 \mathrm{~g}$. The filled consent form was submitted to the animal house in-charge. During the whole study, both control and tested rats were kept in plastic cages with a controlled temperature of $23^{\circ} \mathrm{C} \pm 2{ }^{\circ} \mathrm{C}$ and humidity of $50-60 \%$ in a $12 \mathrm{~h}$ light-dark cycle. Animal handling was performed according to the care and use of Laboratory Animals guidelines provided by the National Institute of Health (NIH). Moreover, the study was approved by a local departmental animal ethical committee of Pakistan Council of Scientific and Industrial Research (PCSIR), Karachi-Pakistan with the approval number of $05 / 04 / \mathrm{KK} / \mathrm{PCSIR}$. At the end of the study, the animals were sacrificed using the cervical dislocation method with all possible effort being given to minimize suffering. Prior to euthanasia, each animal was sedated with an intravenous injection of medetomidine in the concentration of $2 \mu \mathrm{g} / \mathrm{kg}$ [30].

\section{Cotton pellet induced granuloma in rats}

Animals were divided into five groups and each group was composed of 10 rats. Three test groups were received NOEE in the concentrations of 125, 250 and 500 $\mathrm{mg} / \mathrm{kg}$, standard group was taken $10 \mathrm{mg} / \mathrm{kg}$ of indomethacin (Epoch Pharmaceutical Ltd. Pakistan) while distilled water was administered to the control group. After 1st dose of administration, approximately $10 \mathrm{mg}$ of the aseptic cotton pellet was implanted subcutaneously in the back area of the anesthetized animals and treated once daily with standard and test solutions for 7 days. On the 8th day, animals were killed and implanted cotton pellets were removed and dried using a hot air oven at $65^{\circ} \mathrm{C}$. Then, weighed the pellets and calculate the weight gained after implantation, which was considered as granuloma formation [31].

The percent inhibition (PI) of granuloma formation in treated animals was calculated in comparison with a control group using the following formula:

$\mathrm{PI}=\frac{\text { Weight of cotton pellet in control group-Weight of cotton pellet in treated group }}{\text { Weight of cotton pellet in control group }} \times 100$

\section{Carrageenan-induced edema in the rat paw}

Six groups of animals were used in which $20 \mathrm{mg} / \mathrm{kg}$ of diclofenac sodium (Barrett Hodgson Ltd., Pakistan) was given to the standard group, Naive group had not received any type of treatment or carrageenan while the remaining groups were received the same as described in cotton pellet induced granuloma study. After 1st dose administration, inflammation was induced by given 0.1 $\mathrm{mL}(1 \%)$ carrageenan (Kasei chemical industry, Japan) in the right hind paw. Plethysmometer was used to measure the edema in the rat paw at initial and after various times-intervals. Then, the actual volume of edema was measured by subtracting the initial and subsequent readings [32]. The percent inhibition (PI) of edema formation in treated animals was calculated using the following formula:

$\mathrm{PI}=\frac{\text { Mean volume of edema in control group-Mean volume of edema in treated group }}{\text { Mean volume of edema in control group }} \times 100$

\section{Sample preparation of rat paw tissue}

Rats were sacrificed using above defined method after treatment with carrageenan and the paw was harvested immediately. Then the paw was washed with sterile cold saline and stored at $-90^{\circ} \mathrm{C}$ till further use. A paw homogenate $(10 \% \mathrm{w} / \mathrm{v})$ was prepared for biochemical analysis using the $0.1 \mathrm{M}$ sodium phosphate buffer having a $\mathrm{pH}$ of 7.4 with a protease inhibitor cocktail. The prepared homogenate was centrifuged for $15 \mathrm{~min}$ at $9000 \times \mathrm{g}$ and $4{ }^{\circ} \mathrm{C}$. The supernatants were drawn and then stored at $90^{\circ} \mathrm{C}$ until use [33].

\section{Nitrite oxide (NO) assay}

The concentration of nitrite in the supernatant indicated the production of $\mathrm{NO}$ and it was measured using the Griess reaction method [34]. A volume of $100 \mu \mathrm{L}$ supernatant was mixed with the equal volume of Griess 
reagent which containing $50 \mu \mathrm{L}$ aqueous $\mathrm{N}-1$ naphthylethylenediamine dihydrochloride (1\%) and $50 \mu \mathrm{L}$ sulfanilamide (1\%) in phosphoric acid (5\%). Before the sample absorbance was measured at the wavelength of $540 \mathrm{~nm}$ using a microplate reader (BMG, Germany), each sample was incubated at room temperature for 10 min. The amount of nitrite content was given in percentage.

\section{$\mathrm{PGE}_{2}$ assay}

A commercially available kit (R\&D Systems, UK) was utilized for the determination of $\mathrm{PGE}_{2}$ level in the supernatant according to the instructions given by the manufacturer. Briefly, a volume of $50 \mu \mathrm{L}$ supernatant was added in a 96-well plate coated with enzyme-linked $\mathrm{PGE}_{2}$ specific polyclonal antibodies and left for $20 \mathrm{~h}$. After the reaction time, the free antibody-enzyme reagent was removed and the color intensity was measured after the addition of a substrate solution at $450 \mathrm{~nm}$. The $\mathrm{PGE}_{2}$ content was given in percentage.

\section{Cytokine determination}

A commercially available kit (R\&D Systems, UK) was also used to determine the TNF- $\alpha$ and IL- $1 \beta$ levels in the supernatant as per manufacturer instructions. A volume of $100 \mu \mathrm{L}$ supernatant was added in a 96-well plate coated with enzyme-linked rat TNF- $\alpha$ and IL- $1 \beta$ specific polyclonal antibodies and left for $2 \mathrm{~h}$ reaction time. A reaction sample was washed to remove the free reagent of the antibody-enzyme complex. The color intensity was measured after the addition of a substrate solution at $450 \mathrm{~nm}$. The TNF- $\alpha$ and IL-1 $\beta$ levels were given in percentage.

\section{Real-time polymerase chain reaction (PCR) analysis}

A total amount of RNA was isolated from the treated paw using TRIzolR reagent (Gibco, USA). Absorbance was measured at $260 \mathrm{~nm}$ for the calculation of extracted RNA concentrations. However, 260 and $280 \mathrm{~nm}$ absorbance ratio was used for the assessment of RNA quality and 1.9 to 2.1 were the acceptable values of A260/A280. An amount of $1.5 \mu \mathrm{g}$ total RNA was used for the synthesis of cDNA using the cDNA reverse transcription kit (Applied Biosystems, USA). However, PCR analysis was performed using PCR TaqMan master kit $(2 \times)$ (Applied Biosystems, USA) and TaqMan mouse gene expression assays (Applied Biosystems, assay ID: COX-2, Rn01483827_g1; iNOS, Rn00561646_m1; IL-1 $\beta$, Rn00434228_m1; TNF- $\alpha$, Rn02061804_s1 and $\beta$-actin, $\left.\mathrm{Rn} 00667869 \_\mathrm{m} 1\right)$. The reaction times were 2 and $10 \mathrm{~min}$ at $50^{\circ} \mathrm{C}$ and $95^{\circ} \mathrm{C}$ respectively then run 60 cycles for 15 $\mathrm{s}$ at $95^{\circ} \mathrm{C}$ and $1 \mathrm{~min}$ at $60^{\circ} \mathrm{C}$ on a Real-Time PCR system (A453, Applied Biosystems, USA) while data analysis was made using sequence detection software version 2.0 (Applied Biosystems, Inc., USA). The mRNA (TNF- $\alpha$, IL-1 $\beta$, COX-2 and iNOS) relative expressions were normalized with the $\beta$-actin amount in the same cDNA according to the relative $2^{-\Delta \Delta C T}$ quantification method [35]. The fold alteration in the cDNA target gene was determined relative to the $\beta$-actin control using the formula mentioned below:

Fold alteration in $\mathrm{cDNA}=2^{-\Delta \Delta C \mathrm{~T}}$

Where,

$$
\Delta \Delta \mathrm{CT}=\left(\mathrm{Ct}_{\text {target gene }}-\mathrm{Ct}_{\beta \text {-actin }}\right)-\left(\mathrm{Ct}_{\text {control }}-\mathrm{Ct}_{\beta \text {-actin }}\right)
$$

\section{Determination of inflammatory biomarkers}

Determination of leukocytes and C-reactive protein (CRP) levels There are similar 6 groups of rats were used as defined in the carrageenan-induced edema model except for the standard group that was received $100 \mathrm{mg} / \mathrm{kg}$ of acetylsalicylic acid (Atco Laboratories Ltd. Pakistan). After a $3 \mathrm{~h}$ administration of $0.05 \mathrm{~N}$ acetic acid (Sigma-Aldrich, USA), total leukocyte count and CRP levels were measured in peritoneal exudate [36].

Cyclooxygenase- 1 and cyclooxygenase- 2 assay The inhibitory potential of NOEE on COX-1 and COX-2 was evaluated according to the method reported by $\mathrm{Li}$ et al. in 2003 [37]. Briefly, each enzyme was activated by the standard activation method then NOEE and indomethacin (standard) were added individually in each activated enzyme in the concentrations of $1-100 \mu \mathrm{g} / \mathrm{mL}$ and $10 \mu \mathrm{g} / \mathrm{mL}$ respectively. Arachidonic acid (Rofarma-Italia, Italy) was added to start the reaction. The samples were incubated for $10-15 \mathrm{~min}$ at $37^{\circ} \mathrm{C}$ and then terminated the reaction by adding $4 \mathrm{M}$ formic acid. The metabolites of arachidonic acid (prepared during this reaction) were separated and analyzed with the help of a liquid scintillation counter.

5-Lipoxygenase and 12-Lipoxygenase assay The standard and test solutions were treated with the same concentrations used in COX-1 and COX-2 assay with 5lipoxygenase and 12-lipoxygenase individually for 10-15 min at $24{ }^{\circ} \mathrm{C}$. Then arachidonic acid was added to start the enzymatic reactions. The $4 \mathrm{M}$ formic acid was used to acidify the reaction. 5-Hydroxyeicosatetraenoic acid (5-HETE) and 12-HETE were obtained as an end product in 5-lipoxygenase and 12-lipoxygenase enzymatic reactions respectively. The quantities of these by-products were determined using a liquid scintillation counter [37]. 
In vivo acute and sub- toxicity studies

\section{Animals dosing}

Healthy Sprague Dawley rats (10-12 weeks old) of both genders were divided into four groups, with 10 rats in each group. Distilled water was administered to the control group; three groups received $500 \mathrm{mg} / \mathrm{kg}, 1000 \mathrm{mg} / \mathrm{kg}$ and $2000 \mathrm{mg} / \mathrm{kg}$ NOEE once daily orally individually for 28 days. The extract doses for testing were adopted based on a preliminary acute toxicity study on plant extract where a lethal dose $\left(\mathrm{LD}_{50}\right)$ was found to be $>5000$ $\mathrm{mg} / \mathrm{kg}$. The OECD guidelines for toxicity studies were followed for this study [38].

\section{Clinical examinations, body weight and relative organ weights}

After dosing of NOEE, any sign of toxicity was recorded multiple times a day. Plant extract effects were observed on animal general health, behavior, skin and hairs. Initially and after 28 days dosing periods, bodyweight of each rat was noted. In addition, the weight of vital organs was measured and their relative organ weights were calculated on the basis of the total body weight of each rat.

\section{Hematological and biochemical analysis}

Both control and treated rats were sacrificed after the last dosing, $5 \mathrm{~mL}$ blood sample was drawn from the femoral artery of each rat and added in $20 \mathrm{mg} / \mathrm{mL}$ of EDTA (anticoagulant) containing tube for hematological and other biochemical analysis. Blood samples were analyzed to evaluate the change in the number of erythrocytes (RBCs) and white blood cells (WBCs) using an automated blood sample analyzer (Beckman Coulter, U.S). In addition, serum electrolytes, erythrocyte sedimentation rate (ESR) and hemoglobin levels were also estimated. Biochemical analysis was also performed related to the enzymatic levels of the kidney and liver using an autoanalyzer (3400-230, Hitachi, Japan) [39].

\section{Statistical analysis}

All results are given as their mean \pm standard deviation. The antibacterial activity, anti-inflammatory activity and in vivo toxicity findings were subjected to analysis of variance (ANOVA), and post-hoc Tukey tests using SPSS statistical software (version 23). $P<0.05$ and $P<$ 0.005 were considered as the statistical significance and highly statistically significant results respectively. In addition, correlation coefficient and regression analysis were used to determine the relationship among time killing kinetics of different bacterial strains and cell viability respectively.

\section{Results}

Phytochemical screening of NOEE

The ethanolic fraction of $N$. oleander flowers was used for the determination of different phytochemical constituents and their percentage composition. Several phytochemical constituents were found in NOEE in different percentage crude yields such as cardiac glycosides (4.24\%), flavonoids (4.21\%), steroids (3.89\%), terpenes $(3.76 \%)$ alkaloids (3.21\%), saponins $(2.41 \%)$, phenols $(1.92 \%)$ and tannins $(0.11 \%)$ while anthraquinones levels were found in the lowest percentage composition i.e. $0.09 \%$.

\section{Antibacterial susceptibility testing's}

\section{Zone of inhibitions, MIC and MBC values}

The antibacterial activities of different antibiotics and NOEE at different concentrations are presented in Table 1. Among all highly resistant clinical tested isolates; MRSA, S. epidermidis, S. aureus and S. enterica were highly susceptible to the plant extract with the highly significant $(P<0.005)$ ZIs were found i.e. $28.8 \pm 5.74,28.1 \pm 5.44$, $27.8 \pm 6.92$ and $27.7 \pm 4.36$ respectively at the concentration of $30 \mathrm{mg} / \mathrm{mL}$. The values of $\mathrm{MIC} / \mathrm{MBC}$ showed that NOEE has strong bacterial growth inhibitory and bactericidal activity against $S$. aureus $(5.0 / 5.5 \mathrm{mg} / \mathrm{mL})$, B. subtilis (6.5/7.0 mg/mL), MRSA $(8.0 / 8.0 \mathrm{mg} / \mathrm{mL})$ and E. coli $(8.0 /$ $9.0 \mathrm{mg} / \mathrm{mL}$ ) as given in Table $\mathrm{S} 1$.

\section{Antibacterial killing kinetics}

The growth profiles of all tested isolates with respect to time after exposure with the NOEE at MIC of each strain are shown in Fig. 2. This killing kinetics study was carried out for $120 \mathrm{~min}$. NOEE produced a more drop in viable counts of $S$. epidermidis, P. aeruginosa, E. coli, S. enterica and $S$. typhi cells within $20 \mathrm{~min}$. In addition, it was also observed that after exposure to NOEE, all tested isolates showed a stationary phase in bacterial growth after $2 \mathrm{~h}$.

\section{Bacterial killing mechanism}

Figure $3(\mathrm{a}-\mathrm{c})$ displays the morphology of bacterial cells at the initial stage, then after 6 and $12 \mathrm{~h}$ of treatment with NOEE. Figure 3 a shows the normal morphology of $M R S A$ cells at the initial stage of exposure to NOEE while after $6 \mathrm{~h}$ the cells were started to shrink as indicated in Fig. 3 b. However, Fig. 3 c showed that after 12 $\mathrm{h}$ treatment with NOEE, the bacterial cell membrane was completely raptured resulting in the non-viability of MRSA cells

\section{Anti-inflammatory activity}

Overall animal health evaluations such as average weight variation, skin ulceration, loss of activity, diarrhea, hematuria, salivation, tremor, vomiting, edema and aggressive behavior were observed in all control and test 


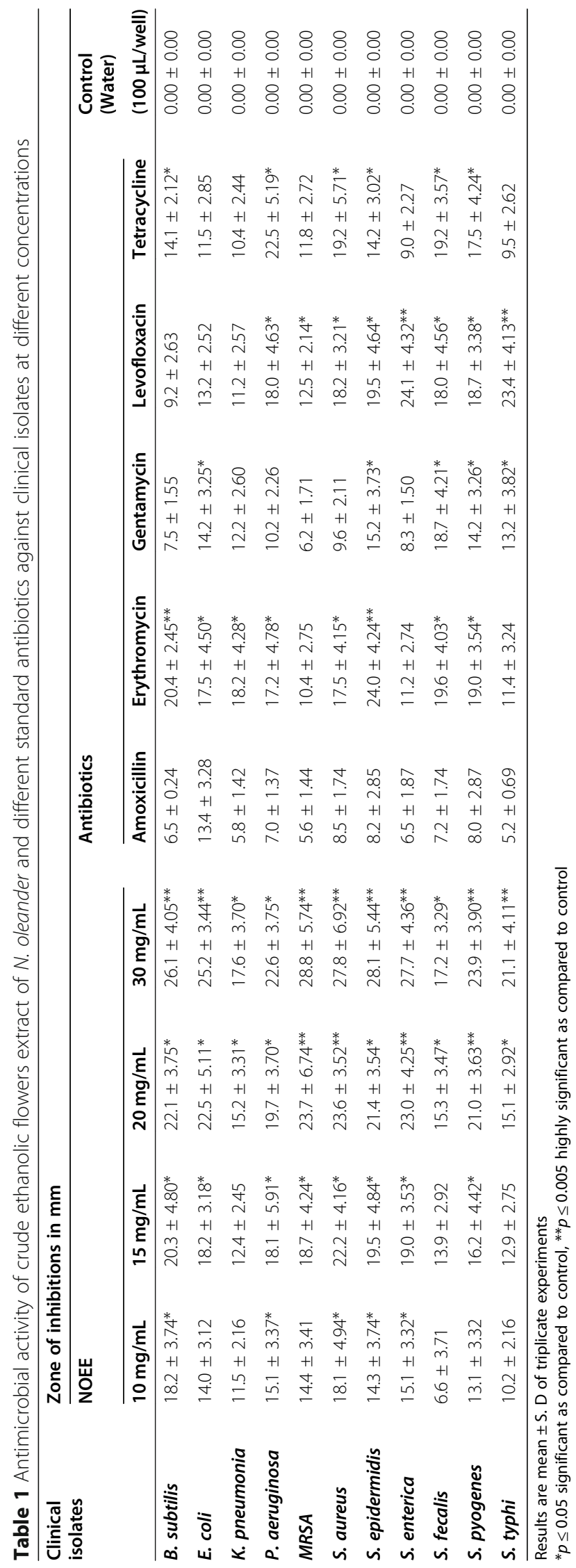




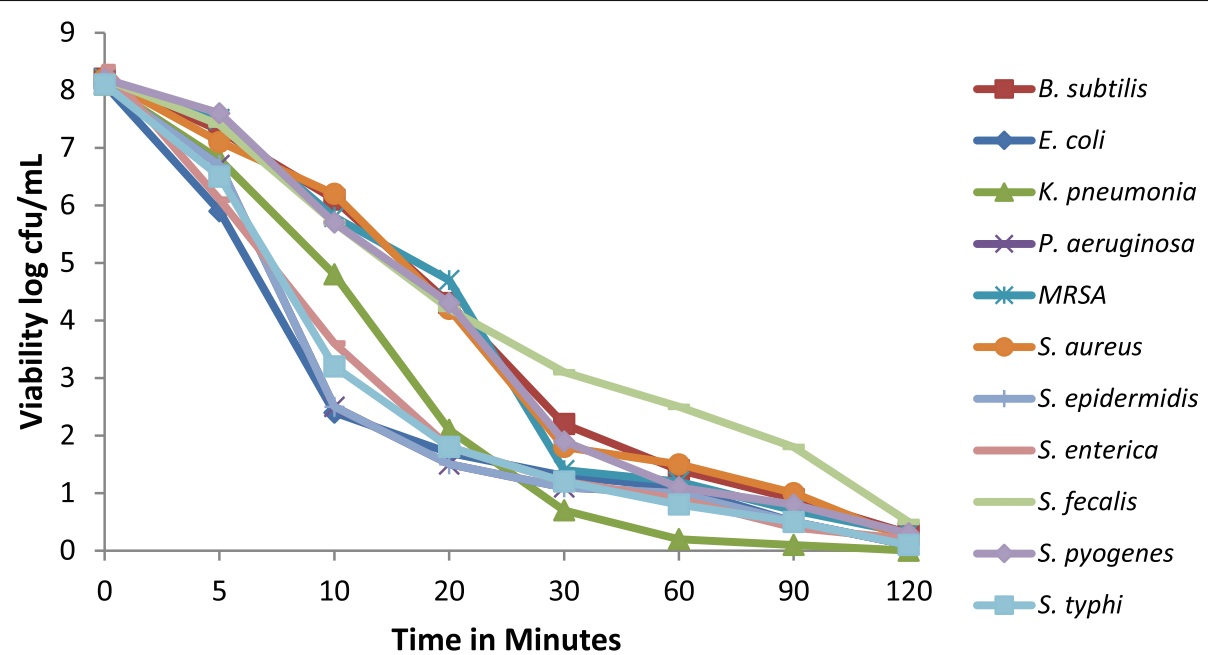

Fig. 2 Growth profile of different isolates at different time interval after exposure to ethanolic extract of Nerium oleander at MBC of each microbe. All experiments were performed in triplicates. Linear relationship $(R 2=0.680)$ among viable cells counts of different bacterial strains at different time intervals while the viable cells counts of all bacterial strains significantly $(R 2=-0.876)$ decreases with increasing exposure time of NOEE

groups before and during the total period of the experiment.

\section{Cotton pellet induced granuloma in rats}

The results of the anti-inflammatory activity of NOEE on granuloma formation induced by a cotton pellet in rats are given in Fig. 4. It was observed that the antiinflammatory effect of NOEE was found to be dose dependent. At 250 and $500 \mathrm{mg} / \mathrm{kg}$ doses of NOEE, a highly significant reduction in inflammation was observed compared with the control $(P<0.005)$. The standard indomethacin at $10 \mathrm{mg} / \mathrm{kg}$ produced very comparable activity with plant extract at $500 \mathrm{mg} / \mathrm{kg}(52.49 \%$ vs. $51.29 \%)$.

\section{Carrageenan-induced edema in the rat paw}

The effects of different concentrations of NOEE on carrageenan-induced edema in rat paw are presented in Fig. 5. The anti-inflammatory activity of NOEE was dose dependent from the 3rd to 6 th $\mathrm{h}$. The significant $(P<$ $0.05)$ and highly significant $(P<0.005)$ inhibitory effects were observed against carrageenan-induced inflammation

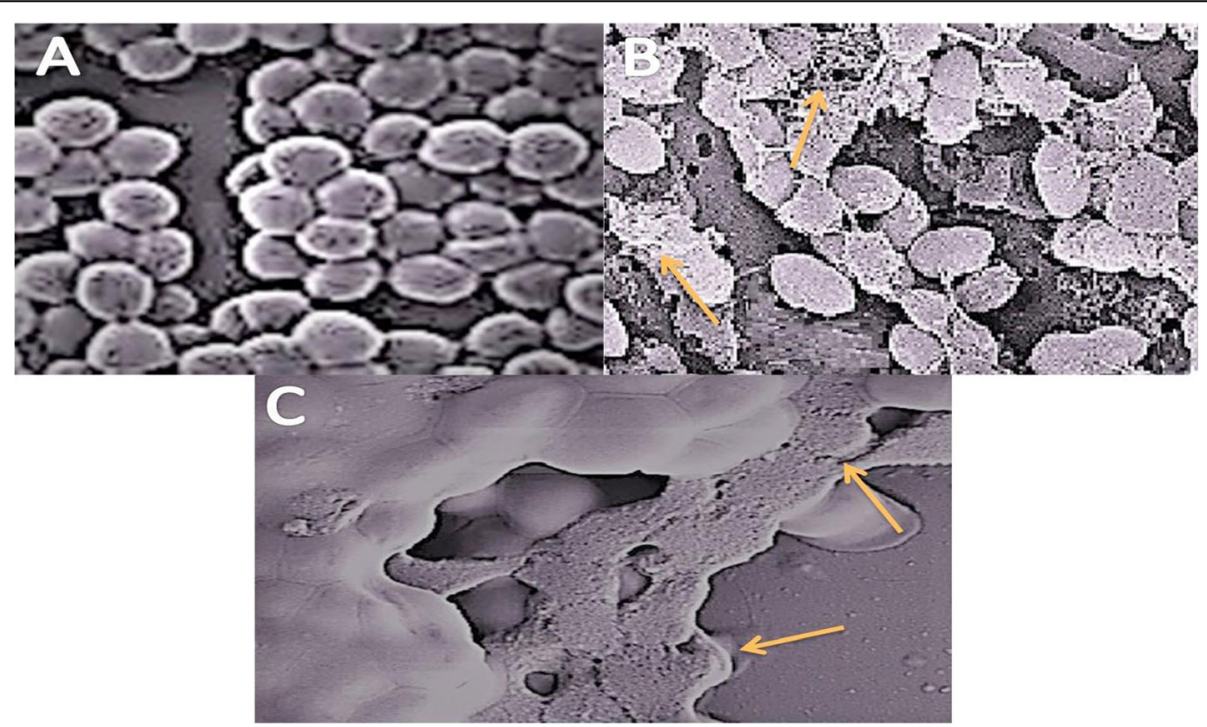

Fig. 3 Morphology of MRSA at initial stage $\mathbf{a}$, after $6 \mathrm{~h} \mathbf{b}$, and $12 \mathrm{~h} \mathbf{c}$, exposed to NOEE at their MIC 


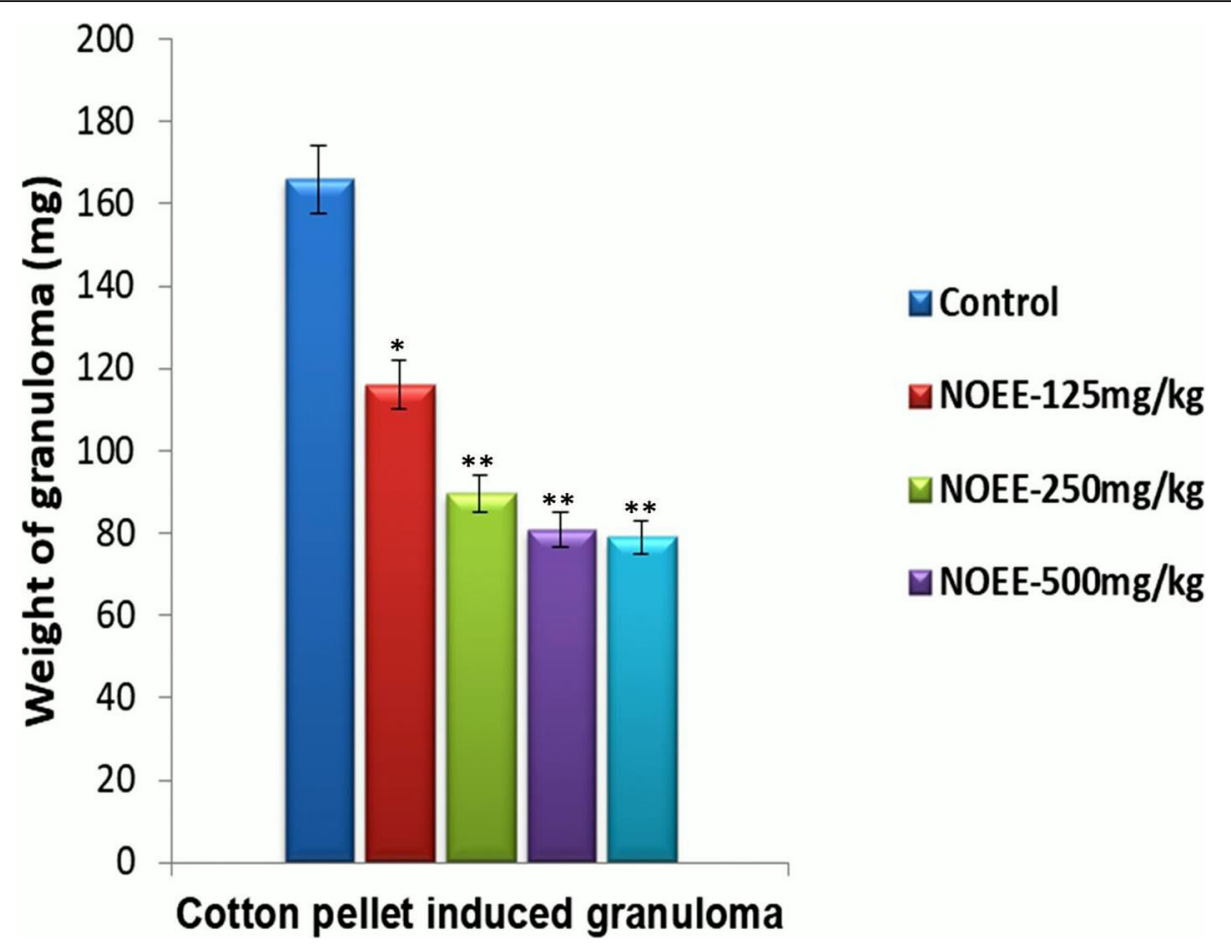

Fig. 4 Effect of the NOEE on cotton pellet induced granuloma in Sprague dawley rats. Values are given as $\bar{x} \pm$ S.E.M. $(n=10),{ }^{*} p \leq 0.05$ and ${ }^{* *} p \leq$ 0.005 significant and highly significant as compared to control

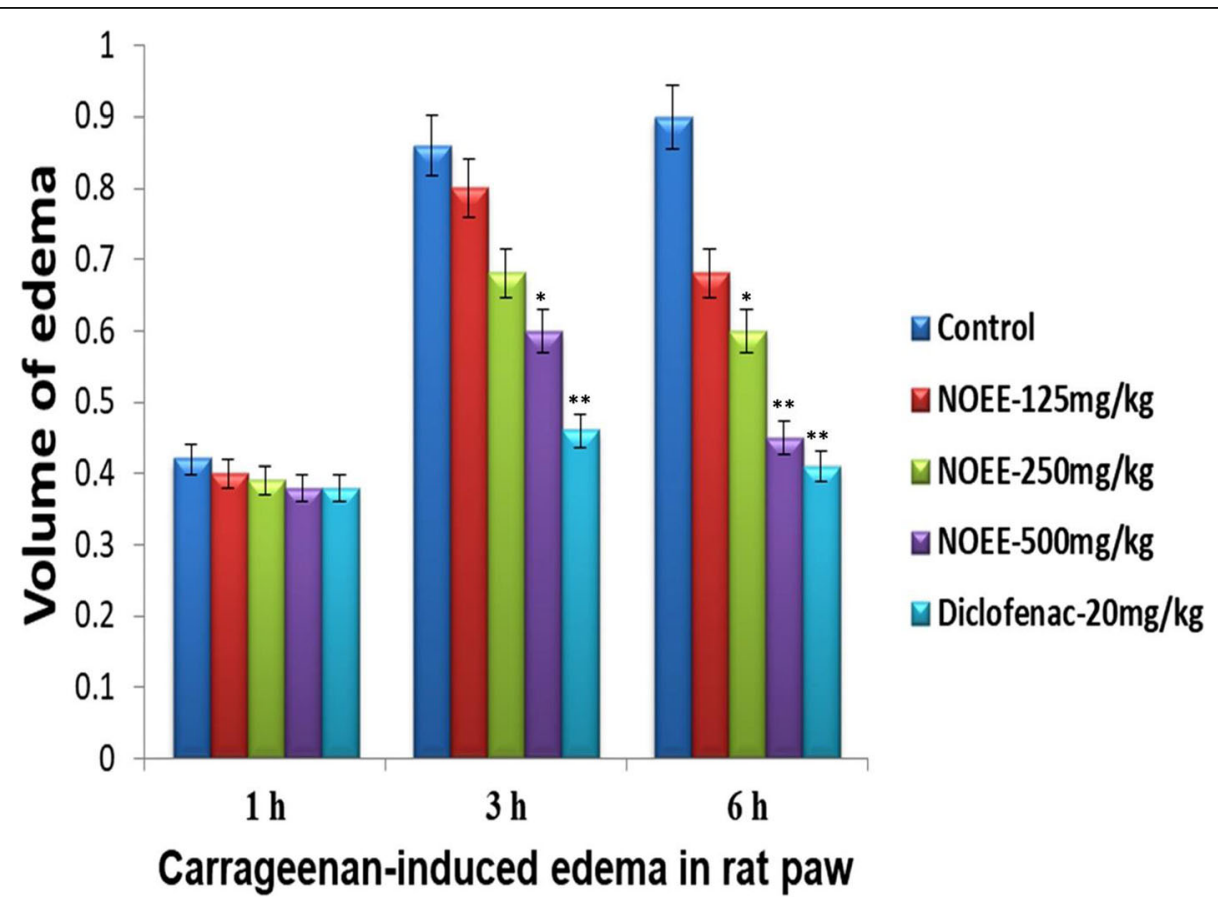

Fig. 5 Effect of the NOEE on carrageenan-induced edema in rat paw; Values are given as $\bar{x} \pm$ S.E.M. $(n=10)$, * $p \leq 0.05$ and ${ }^{* *} p \leq 0.005$ significant and highly significant as compared to control. The naïve group did not show any sign of edema (Naïve $=0.00)$ 
at both doses of NOEE with the inhibition percentages of 37.77 and $50.00 \%$ respectively after $6 \mathrm{~h}$. The antiinflammatory effect of a standard drug (54.44\%) was comparable with the tested plant extract.

\section{Effects of NOEE on the production of NO and iNOS MRNA expression in carrageenan-induced rat paw edema} Figure 6a shows the activity of NOEE on the production of NO while Fig. $6 \mathrm{~b}$ presented the iNOS mRNA expressions in the carrageenan-induced rat paw edema. At 250 $\mathrm{mg} / \mathrm{kg}$ and $500 \mathrm{mg} / \mathrm{kg}$ doses of plant extract, a significant and highly significant reduction was observed in the production of $\mathrm{NO}$ by 42.1 and $55.8 \%$ respectively compared to the control. Similarly, at the doses of 125 , 250 and $500 \mathrm{mg} / \mathrm{kg}$ NOEE, iNOS mRNA expression was also suppressed significantly in dose dependent manner by $38.1,49.5$ and $58.3 \%$ respectively. However, standard indomethacin also attenuated the $\mathrm{NO}$ production (50.1\%) and iNOS (49.6\%) mRNA expressions in a significant manner in comparison to the control group.

\section{Effects of NOEE on the production of $\mathrm{PGE}_{2}$ and $m R N A$ expression of COX-2 in carrageenan-induced rat paw edema}

Figure $7 \mathrm{a}$ and $\mathrm{b}$ present the activity of NOEE on the production of $\mathrm{PGE}_{2}$ and mRNA expression of COX-2 respectively in the carrageenan-induced rat paw edema. NOEE at the dose of 125 and $250 \mathrm{mg} / \mathrm{kg}$, significantly reduced $\mathrm{PGE}_{2}$ production by 55.4 and $62.2 \%$ respectively while highly significant attenuation (65.4\%) was observed

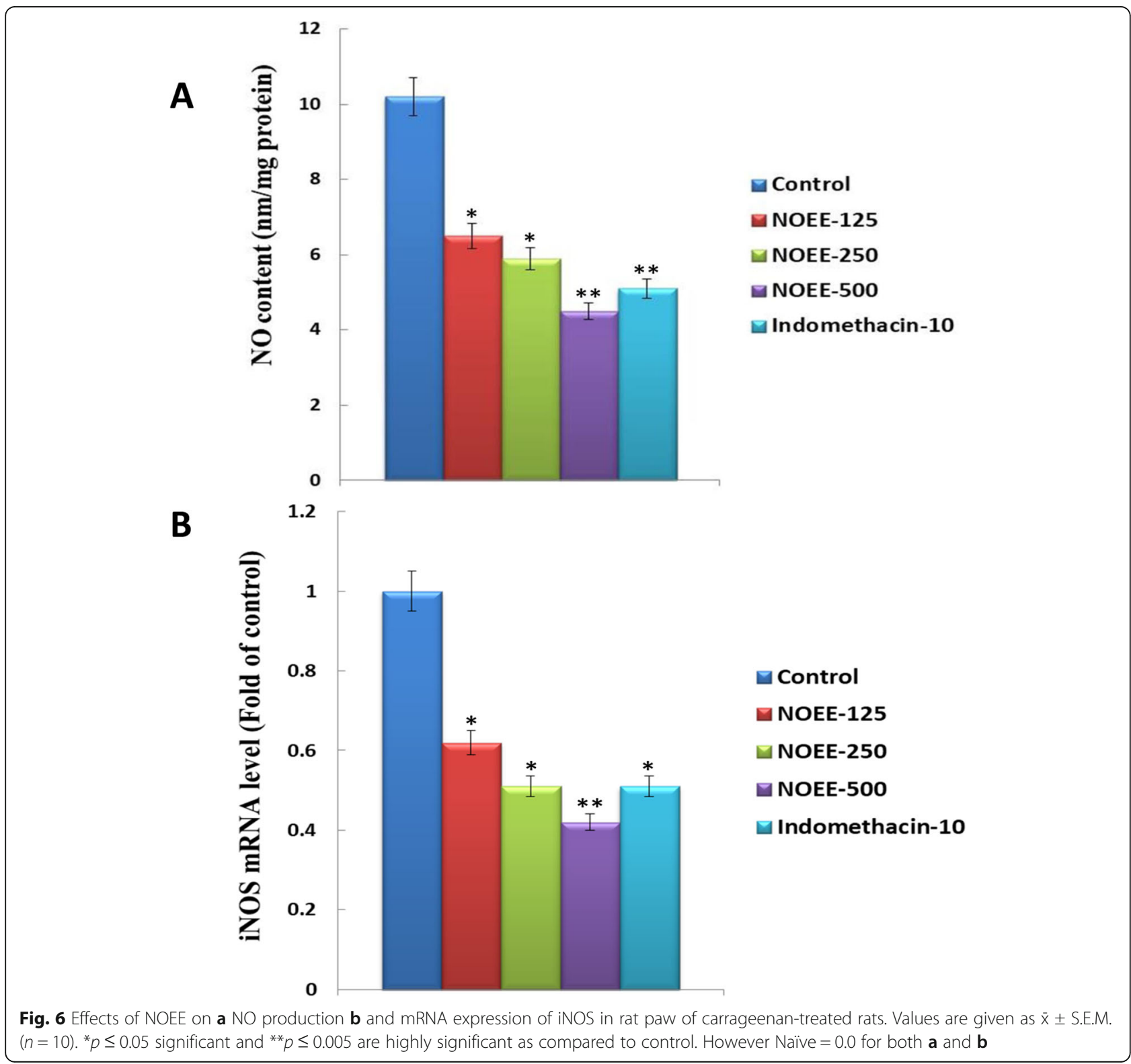




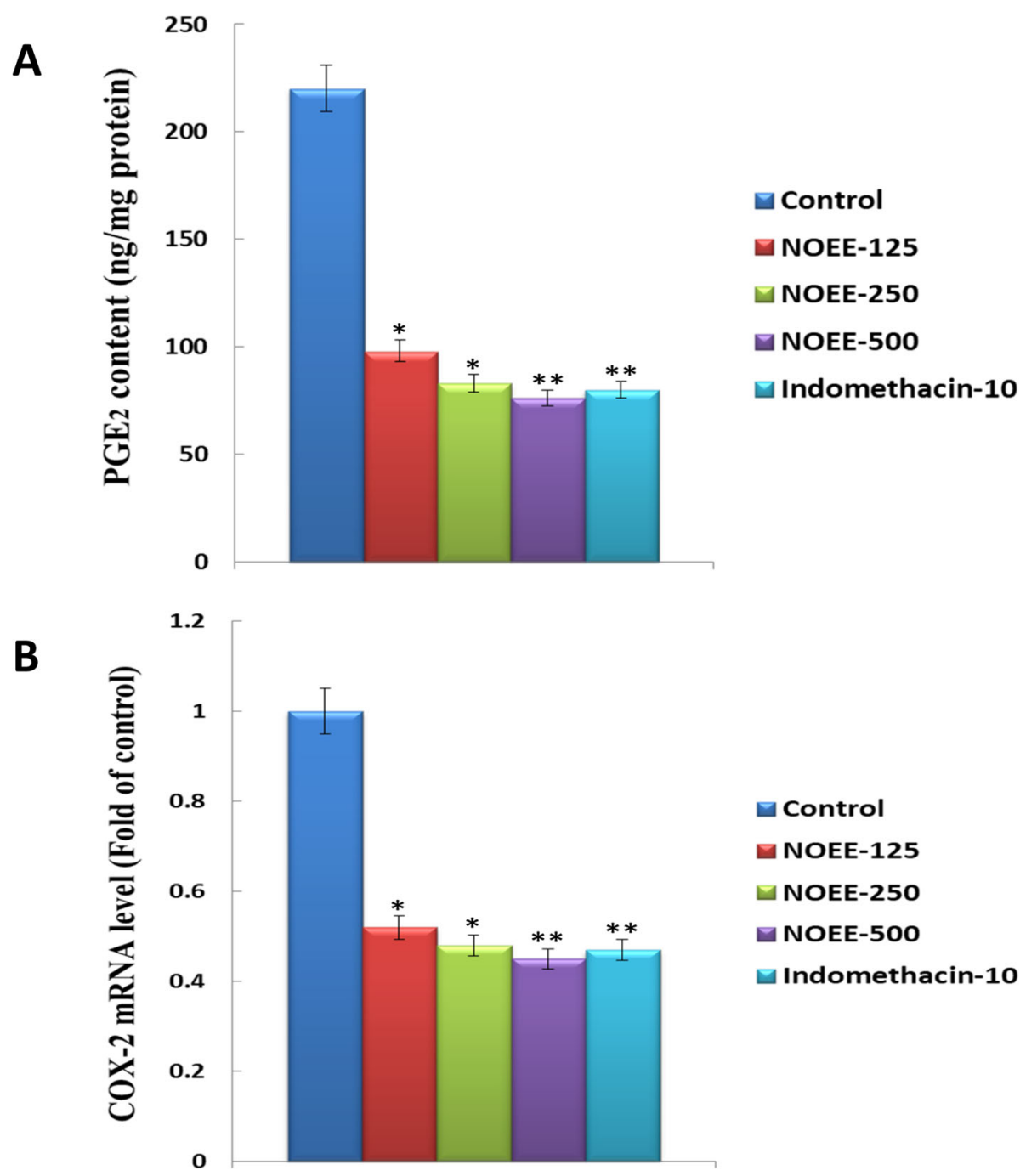

Fig. 7 Effects of NOEE on $\mathbf{a} P \mathrm{PGE}_{2}$ production and $\mathbf{b}$ mRNA expression of COX-2 in rat paw of carrageenan-treated rats. Values are given as $\bar{x} \pm$ S.E.M. $(n=10) .{ }^{*} p \leq 0.05$ significant and ${ }^{* *} p \leq 0.005$ are highly significant as compared to control. However Naïve group $=0.0$ for both $\mathbf{a}$ and $\mathbf{b}$

at the dose of $500 \mathrm{mg} / \mathrm{kg}$ as compared to the control group. NOEE reduced the COX-2 mRNA expression in the ranges of 36.2 to $55.8 \%$ while a highly significant effect was observed at the dose of $500 \mathrm{mg} / \mathrm{kg}$ i.e. $55.8 \%$. Furthermore, the achieved outcomes were much comparable with a standard group for the reduction of $\mathrm{PGE}_{2}$ production and COX-2 mRNA expression by 63.6 and $50.3 \%$ respectively.

Effects of NOEE on the production of TNF- $\alpha$ and IL-1 $\beta$ and their mRNA expression in carrageenan-induced rat paw edema

The effects of different concentrations of NOEE on TNF- $\alpha$ and IL- $1 \beta$ levels in carrageenan-induced rat paw edema are presented in Fig. 8a and b respectively. The dose-dependent suppressions in TNF- $\alpha$ and IL- $1 \beta$ levels were observed in the ranges of 46.6 to $60.1 \%$ and 28.3 to $68.4 \%$ respectively after treatment with NOEE at different doses. At 250 and $500 \mathrm{mg} / \mathrm{kg}$ doses of NOEE, significant and highly significant down-regulation in mRNA expressions of TNF- $\alpha$ compared with the control i.e. 50.2 and $60.7 \%$ respectively (Fig. 8c). Consistent with the findings of IL-1 $\beta$ levels, Fig. 8d also shows that NOEE remarkably reduced the mRNA expression of IL- $1 \beta$ in a dose-dependent manner. In addition, indomethacin at $10 \mathrm{mg} / \mathrm{kg}$ showed very similar effects to that of NOEE at $500 \mathrm{mg} / \mathrm{kg}$.

\section{Determination of inflammatory biomarkers}

The reduction in total leukocyte count and CRP levels by NOEE in peritoneal exudate after acetic acid-induced peritoneal inflammation are shown in Figs. 9, and 10 respectively. At $250 \mathrm{mg} / \mathrm{kg}$ and $500 \mathrm{mg} / \mathrm{kg}$ doses of plant 
A

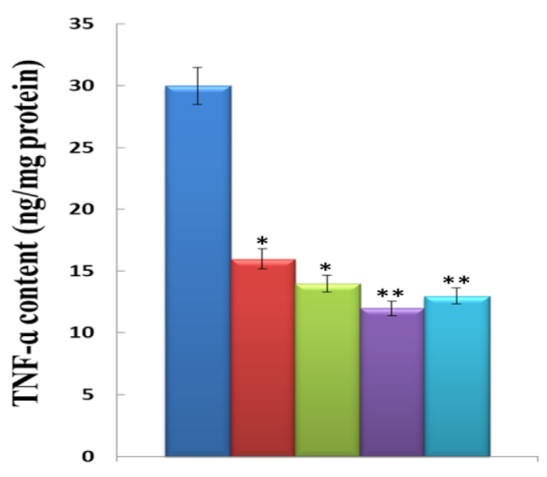

C

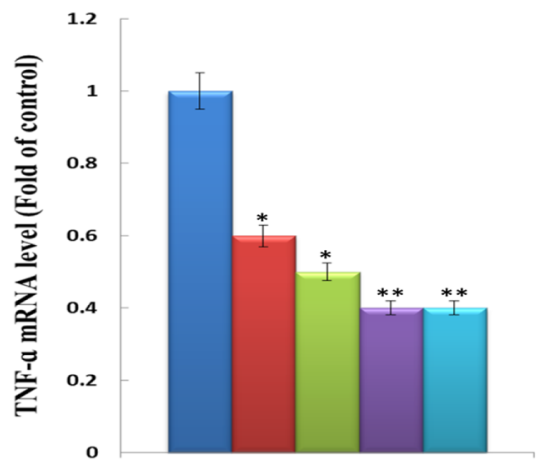

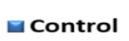

$\square$ NOEE-125

$\triangle$ NOEE-250

$\square$ NOEE-500

$\square$ Indomethacin-10

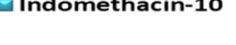

B

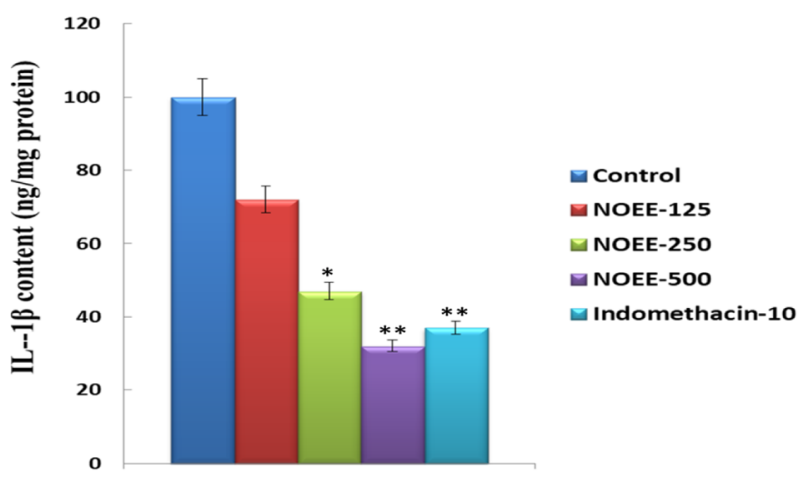

D

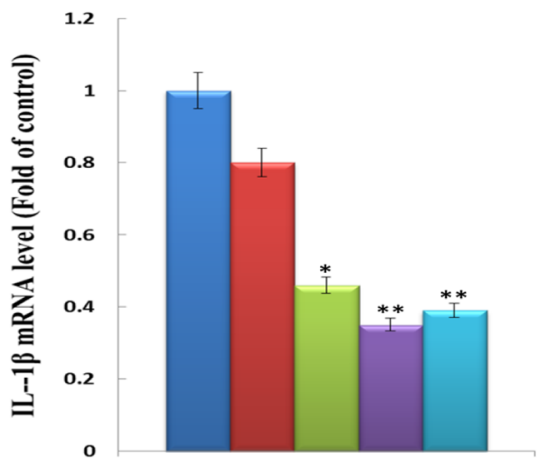

$\square$ Control

- NOEE-125

$\triangle$ NOEE-250

- NOEE-500

$\square$ Indomethacin-10

Fig. 8 Effects of NOEE on the production of $\mathbf{a}$ TNF- $\mathrm{a}$ and $\mathbf{b} I \mathrm{~L}-1 \beta$ while $\mathbf{c}$ and $\mathbf{d}$ show mRNA expression of TNF- $\mathrm{a}$ and $\mathrm{IL}-1 \beta$ respectively in rat paw of carrageenan-treated rats. Values are given as $\bar{x} \pm$ S.E.M. $(n=10) .{ }^{*} p \leq 0.05$ significant and ${ }^{* *} p \leq 0.005$ are highly significant as compared to control. However Naïve group $=0.0$

extract, significant $(P<0.05)$ and highly significant $(P<$ $0.005)$ reductions were observed in total leukocyte count and CRP levels. Highly significant reduction in total leukocyte count (73.09\%) and CRP levels (54.60\%) were found after treatment with NOEE at $500 \mathrm{mg} / \mathrm{kg}$. However, the percentage reduction of extract was much lesser than acetylsalicylic acid at the dose of $10 \mathrm{mg} / \mathrm{kg}$ i.e. 81.63 and $63.80 \%$ reduction in total leukocyte count and CRP levels respectively.

The percentage inhibition of COX-1, COX-2, 5-LO and 12-LO by NOEE at the concentrations of 10, 50 and $100 \mu \mathrm{g} / \mathrm{mL}$ are presented in Fig. 11a. NOEE demonstrated COX-1 inhibition in dose dependent manner with the percentage inhibitions of $16.1,52.4$ and $72.9 \%$ at the doses of 10,50 and $100 \mu \mathrm{g} / \mathrm{mL}$ respectively. However, inhibition of COX-2 by NOEE was much greater than COX-1 inhibition. Similarly, NOEE exhibited marginally potent 12 -LO inhibition (57.6\%) compared to 5LO inhibition (55.7\%) at the concentration of $100 \mu \mathrm{g} /$ $\mathrm{mL}$. Moreover, the $\mathrm{IC}_{50}$ value of NOEE was much comparable with the indomethacin (standard) on COX-1, COX-2, 5-LO and 12-LO as presented in Fig. 11b. In addition, NOEE showed lower $\mathrm{IC}_{50}$ value for $\mathrm{COX}-1$ and
COX-2 $(42.4 \mu \mathrm{g} / \mathrm{mL}$ and $37.5 \mu \mathrm{g} / \mathrm{mL})$ than $5-\mathrm{LO}$ and $12-$ LO $(68.8 \mu \mathrm{g} / \mathrm{mL}$ and $76.4 \mu \mathrm{g} / \mathrm{mL})$.

In vivo acute and sub- toxicity studies

Clinical examinations, body weight and relative organ weights

Initially, the acute toxicity of NOEE was studied in rats for 14 days. No significant sign of toxicity was observed in tested rats after 14 days of oral administration of NOEE. The $\mathrm{LD}_{50}$ value of NOEE was found to be > $5000 \mathrm{mg} / \mathrm{kg}$. In the sub-acute toxicity study, Table S2 shown that no significant changes in the body and relative organ weights were observed in both gender tested groups compared to the control group $(P>0.05)$. All tested animals had survived with no sign of abnormalities during the 28 days study period.

\section{Hematological and biochemical analysis}

After administration of NOEE, there were no significant changes found in the blood profile of studied groups in both male and female groups of animals as compared to control (Table 2). Moreover, no abnormalities were observed in serum levels of sodium, potassium and calcium 

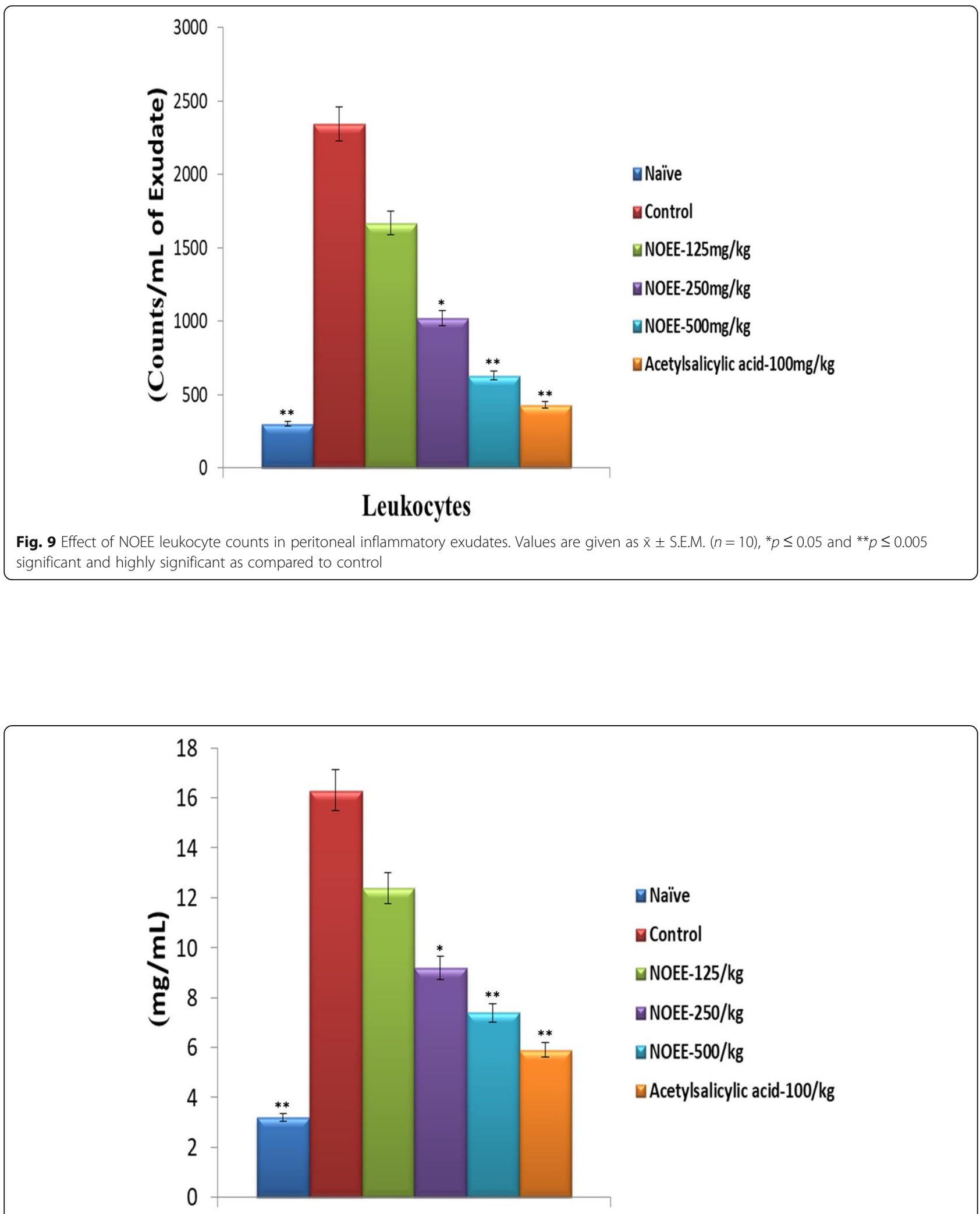

\section{C-Reactive Protein}

Fig. 10 Effect of NOEE C-reactive protein levels in peritoneal inflammatory exudates. Values are given as $\bar{x} \pm$ S.E.M. $(n=10),{ }^{*} p \leq 0.05$ and ${ }^{* *} p \leq$ 0.005 significant and highly significant as compared to control 


\section{A}

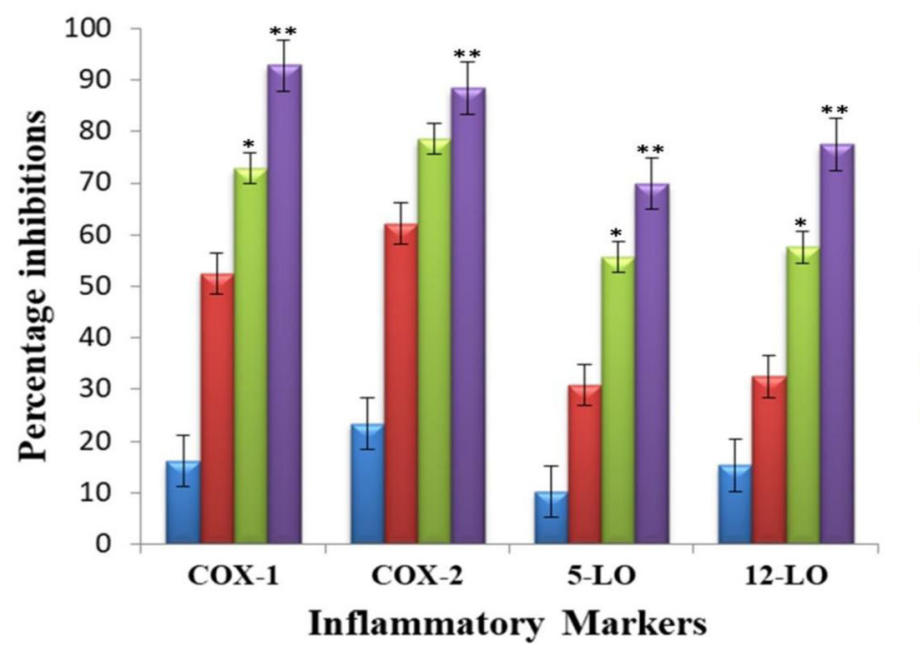

B

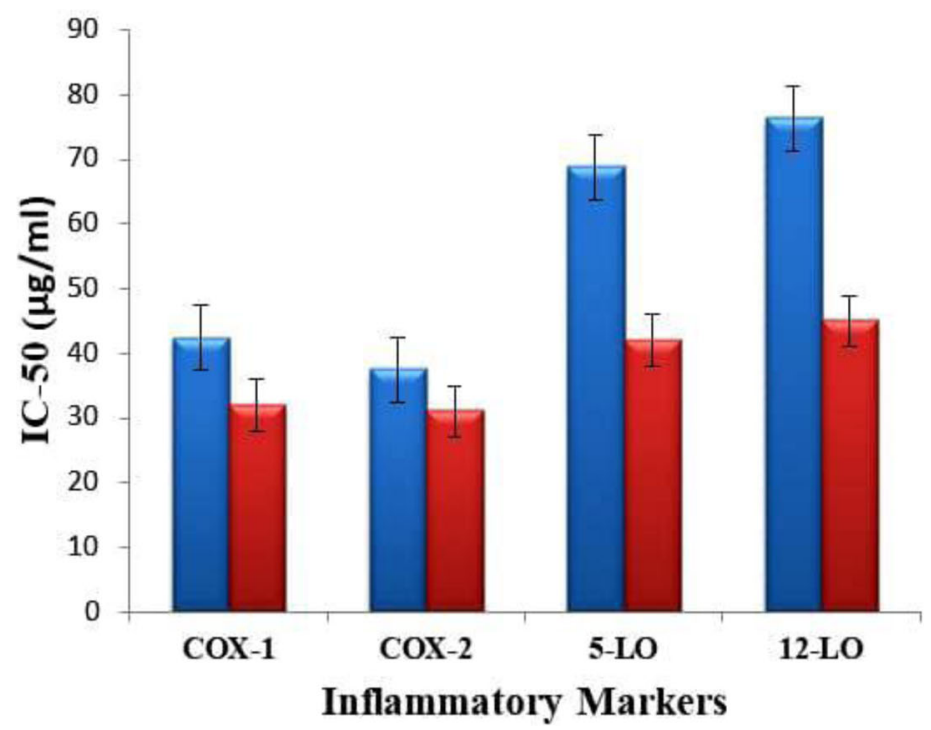

口NOEE

Elndomethacin

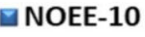

$\square$ NOEE-50

$\square$ NOEE-100

Indomethacin-100

Fig. 11 a Inhibition of COX-1, COX-2, 5-LO and 12-LO by NOEE $\mathbf{b} I \mathrm{C}_{50}$ values of NOEE and indomethacin on COX-1, COX-2, 5-LO and 12-LO. Values are given as $\bar{X} \pm$ S.E.M. $(n=10){ }^{*} p \leq 0.05$ significant as compared to control, ${ }^{* *} p \leq 0.005$ highly significant as compared to control

during sub-acute toxicity studies. At three different doses of NOEE, a significant increase of alkaline phosphatase (ALP), aspartate transaminase (AST), alanine transaminase (ALT) and bilirubin levels were observed at the dose of $2000 \mathrm{mg} / \mathrm{kg}$ in both genders groups compared to control groups. In contrast, the normal levels of creatinine, blood urea nitrogen (BUN) and uric acid were observed at all doses of NOEE.

\section{Discussion}

In order to assess the antimicrobial potential of ethanolic flower extract of $N$. oleander, different concentrations were used against various highly resistant Gram-positive and Gram-negative clinical isolates. An antibiotic susceptibility test was also performed against clinical isolates. The extract showed significant results against MRSA and S. epidermidis in dose dependent manner followed by $S$. aureus and $S$. enterica. The extract is found to be highly sensitive against $S$. aureus at the lowest dose of $10 \mathrm{mg} / \mathrm{mL}$. This organism is usually involved in skin infections and lesions and many antibiotics were already reported for their resistance pattern against this organism [40]. Test compound showed more powerful results against Gram-positive isolates compares to 
Gram-negative. Amoxicillin and gentamycin were found to be the most resistant antibiotics against most resistant clinical isolates. However, the statistical analysis reflects significant antibacterial potential between commercial antibiotics and experimental herbal extract. Obtained results are also in agreement with Namian et al. who investigated the antibacterial potential of flower extract of this plant in crude as well as in fraction form against 3 gram-negative and 3 gram-positive bacterial strains [41]. A crude extract was found to be more effective than purified fraction with significant results. The strong outcomes of the present study might be due to the selection of ethanol as extracting solvent since the importance of solvent extraction in obtaining powerful antimicrobial action has already been reported [42].

At present, limited data are available on time-killing kinetics of antimicrobials obtained by their MICs. In addition our study observed that NOEE shows inhibition in bacterial growth as well as organism proliferation at the same concentration against few tested strains. Due to this fact, time-killing assay was performed to acquire the relationship between incubation time, the concentration of antimicrobial agent and the rate of bactericidal activity [22]. NOEE showed significant bactericidal and bacteriostatic effects after short exposure with the tested isolates. It was observed that the extract produced bactericidal effects against most of the tested isolates within $2 \mathrm{~h}$. The findings of the time killing assay showed that the extract produced their bactericidal effects more rapidly against Gram-negative organisms.

Previously several studies reported the bacterial killing mechanism of different antibacterial agents using the SEM technique $[43,44]$. The present study findings demonstrated that the extract was highly susceptible against MRSA among all other tested isolates. Therefore, SEM analysis was carried out on MRSA cells by examined the morphological changes in cells after exposure with NOEE to illustrate the possible bacterial killing mechanism of NOEE. The significant morphological and cytological alterations in bacterial cell membrane were observed and cells were completely lysed and collapsed after $12 \mathrm{~h}$ treatment with NOEE. This could be suggested that NOEE had a high binding affinity with the bacterial cell membrane lipopolysaccharides. This extract-lipopolysaccharide interaction significantly altered the morphology of the bacterial cell membrane [45]. Similar alterations in the morphology of bacterial cells were reported in previous studies after treatment with different plant extracts at their MICs. For instance, Shafiq et al., and Mumtaz et al. observed much identical rapturing in the membrane of MRSA and S. pneumonia cells after treated with Casuarina equisetifolia and Sphaeranthus indicus respectively $[9,28]$.
To evaluate the anti-inflammatory effects of plant extract, it is very important to find the extract effectiveness in both early and late phases of inflammation. Here two well-established animal models were used to investigate the anti-inflammatory activity of NOEE. The granuloma induced by cotton pellet is a commonly reported method in animal studies for the evaluations of late phase (chronic) anti-inflammatory potential of testing a drug or any other anti-inflammatory agents. The cotton pellet implantation in the subcutaneous region is directly responsible for the activation of acute inflammation. Later, this acute inflammation eventually leads to a chronic phase [36]. NOEE showed significant inhibition of cotton pellet induced granuloma formation at doses of 125 , 250 and $500 \mathrm{mg} / \mathrm{kg}$. Hence, the data of this model suggested that the NOEE has significant potential to produced anti-inflammatory activity at the chronic phase of inflammation.

To screen the anti-inflammatory activity of the test solution, carrageenan-induced acute inflammation is supposed to be the most suitable test. In this model, edema development is considered as a biphasic curve since the inflammation occurs in 1st $\mathrm{h}$ either by trauma injection or due to the release of histamine and serotonin [32]. However, it was observed that no reduction in edema in the early hours at all doses of NOEE. Although in the second phase of inflammation ( $3 \mathrm{rd} \mathrm{h}$ ), a considerable reduction in paw edema was noticed at the dose of 500 $\mathrm{mg} / \mathrm{kg}$. Our results are in streamline with the study of Erdemoglu et al. who reported the significant antiinflammatory activity of different plants belongs to the Apocynaceae family [46]. The inhibitory effects of the experimental extract might be observed due to the inhibition of the cyclooxygenase pathway, which leads to the inhibition of prostaglandins [36].

The involvement of COX-2 expression in the progression of inflammatory pathogenesis was observed in various diseases such as central nervous systems, gastrointestinal tract, ischemia and inflammation of the lung and liver $[47,48]$. In the present study, NOEE reduced $\mathrm{PGE}_{2}$ production and $\mathrm{COX}-2$ mRNA expression in carrageenan-induced rat paw edema in a dosedependent manner, indicating that NOEE produced anti-inflammatory activity by inhibiting the expression of COX-2 mRNA level.

TNF- $\alpha$ and IL- $1 \beta$ are the highly substantial inflammatory mediators reported in association with several inflammatory diseases including rheumatoid arthritis, bacterial sepsis, skin inflammation and many others [49, 50]. At an initial inflammatory stage, the release of these pro-inflammatory cytokines is observed in response to various inflammatory stimuli resulting in the increased production of inflammatory mediators such as prostaglandins and NO [51]. Furthermore, TNF- $\alpha$ and IL-1 $\beta$ 
Table 2 Effects of different concentration of NOEE on serum electrolyte levels, blood profile and liver profile in Sprague Dawley rats

\begin{tabular}{|c|c|c|c|c|c|c|c|c|}
\hline \multirow[t]{3}{*}{ Parameters } & \multicolumn{8}{|c|}{ Groups* (mean \pm S.D) } \\
\hline & \multicolumn{4}{|c|}{ Male } & \multicolumn{4}{|l|}{ Female } \\
\hline & Control & $\begin{array}{l}\text { NOEE } \\
(500 \mathrm{mg} / \mathrm{kg})\end{array}$ & $\begin{array}{l}\text { NOEE } \\
(1000 \mathrm{mg} / \mathrm{kg})\end{array}$ & $\begin{array}{l}\text { NOEE } \\
(2000 \mathrm{mg} / \mathrm{kg})\end{array}$ & Control & $\begin{array}{l}\text { NOEE } \\
(500 \mathrm{mg} / \mathrm{kg})\end{array}$ & $\begin{array}{l}\text { NOEE } \\
(1000 \mathrm{mg} / \mathrm{kg})\end{array}$ & $\begin{array}{l}\text { NOEE } \\
(2000 \mathrm{mg} / \mathrm{kg})\end{array}$ \\
\hline \multicolumn{9}{|l|}{ Serum electrolytes } \\
\hline $\mathrm{Na}^{+}(\mathrm{mEq} / \mathrm{L})$ & $132.1 \pm 5.21$ & $137.3 \pm 7.52$ & $136.2 \pm 7.46$ & $134.6 \pm 8.57$ & $134.5 \pm 5.71$ & $138.2 \pm 7.03$ & $135.7 \pm 7.81$ & $136.2 \pm 9.72$ \\
\hline $\mathrm{K}^{+}(\mathrm{mEq} / \mathrm{L})$ & $5.26 \pm 0.57$ & $5.64 \pm 0.48$ & $5.69 \pm 1.56$ & $5.73 \pm 0.98$ & $5.87 \pm 0.89$ & $5.63 \pm 0.73$ & $5.79 \pm 0.42$ & $5.92 \pm 0.67$ \\
\hline $\mathrm{Ca}^{+}(\mathrm{mEq} / \mathrm{L})$ & $5.10 \pm 0.52$ & $5.36 \pm 0.52$ & $5.18 \pm 1.28$ & $5.23 \pm 0.92$ & $5.16 \pm 0.73$ & $5.21 \pm 0.70$ & $5.41 \pm 0.67$ & $5.25 \pm 0.31$ \\
\hline \multicolumn{9}{|l|}{ Blood profile } \\
\hline $\operatorname{RBCs}\left(10^{12} / \mathrm{L}\right)$ & $8.38 \pm 0.42$ & $8.26 \pm 0.78$ & $8.31 \pm 0.32$ & $8.12 \pm 0.47$ & $7.89 \pm 0.93$ & $7.83 \pm 0.46$ & $7.67 \pm 0.92$ & $7.92 \pm 0.58$ \\
\hline WBCs $\left(10^{9} / \mathrm{L}\right)$ & $13,351 \pm 5242$ & $13,831 \pm 3170$ & $13,687 \pm 5904$ & $14,073 \pm 5340$ & $11,920 \pm 5027$ & $11,804 \pm 3737$ & $12,034 \pm 4329$ & $11,974 \pm 4542$ \\
\hline Hb levels (g/dL) & $14.23 \pm 1.04$ & $14.19 \pm 0.75$ & $14.71 \pm 0.68$ & $14.45 \pm 0.72$ & $13.06 \pm 0.82$ & $13.71 \pm 0.27$ & $13.43 \pm 0.52$ & $13.74 \pm 0.63$ \\
\hline ESR $(\mathrm{mm} / \mathrm{h})$ & $1.41 \pm 0.21$ & $1.39 \pm 0.23$ & $1.34 \pm 0.52$ & $1.56 \pm 0.42$ & $1.49 \pm 0.23$ & $1.41 \pm 0.47$ & $1.47 \pm 0.76$ & $1.42 \pm 0.53$ \\
\hline \multicolumn{9}{|l|}{ Liver profile } \\
\hline ALP (U/L) & $209.47 \pm 25.7$ & $225.41 \pm 77.6$ & $219.56 \pm 54.0$ & $257.65 \pm 56.5^{*}$ & $228.60 \pm 56.3$ & $241.38 \pm 59.3$ & $257.19 \pm 27.6$ & $270.41 \pm 38.3^{*}$ \\
\hline AST (U/L) & $233.72 \pm 39.4$ & $242.40 \pm 27.1$ & $278.37 \pm 36.8$ & $289.56 \pm 57.5^{*}$ & $212.49 \pm 44.3$ & $209.37 \pm 57.6$ & $236.98 \pm 38.2$ & $261.09 \pm 26.1^{*}$ \\
\hline $\mathrm{ALT}(\mathrm{U} / \mathrm{L})$ & $41.21 \pm 14.27$ & $45.79 \pm 11.08$ & $42.13 \pm 6.25$ & $46.19 \pm 5.43^{*}$ & $51.10 \pm 14.31$ & $54.08 \pm 9.40$ & $58.97 \pm 8.73$ & $71.37 \pm 9.33^{*}$ \\
\hline Bilirubin (mg/dL) & $0.72 \pm 0.21$ & $0.61 \pm 0.27$ & $0.67 \pm 0.13$ & $0.73 \pm 0.22^{*}$ & $0.54 \pm 0.14$ & $0.52 \pm 0.12$ & $0.63 \pm 0.37$ & $0.72 \pm 0.29^{*}$ \\
\hline \multicolumn{9}{|l|}{ Kidney profile } \\
\hline Creatinine (mg/dL) & $1.82 \pm 0.44$ & $1.84 \pm 0.24$ & $1.78 \pm 0.31$ & $1.80 \pm 0.17$ & $1.10 \pm 0.24$ & $1.05 \pm 0.42$ & $1.23 \pm 0.19$ & $1.10 \pm 0.15$ \\
\hline BUN (mg/dL) & $26.30 \pm 3.21$ & $24.51 \pm 2.87$ & $24.05 \pm 4.18$ & $22.96 \pm 3.84$ & $25.27 \pm 2.89$ & $26.97 \pm 3.72$ & $26.33 \pm 2.94$ & $25.94 \pm 4.68$ \\
\hline Uric acid (mg/dL) & $1.73 \pm 0.24$ & $1.75 \pm 0.18$ & $1.68 \pm 0.23$ & $1.72 \pm 0.15$ & $1.64 \pm 0.28$ & $1.67 \pm 0.20$ & $1.72 \pm 0.12$ & $1.64 \pm 0.34$ \\
\hline
\end{tabular}

NOEE Nerium oleander ethanolic extract, RBCs Red blood cells, WBCs White blood cells, Hb Hemoglobin, ESR Erythrocyte sedimentation rate, $A L P$

Alkaline phosphatase;

AST Alkaline phosphatase, ALT Alanine transaminase, BUN Blood urea nitrogen

${ }^{*} p \leq 0.05$ significant as compared to control

are also responsible for the inflammatory responses involved in carrageenan-induced inflammation [52]. It is reported that TNF- $\alpha$ mediates the production of IL- $1 \beta$, which causes the release of cyclooxygenase enzyme [53]. However, the oxidation L-arginine nitrogen atom by the enzyme nitric oxide synthase (NOS) is responsible for the generation of $\mathrm{NO}$. This $\mathrm{NO}$ is also contributing to the inflammatory responses, produced in carrageenaninduced inflammation [54]. Similarly, it is also found that $\mathrm{NO}$ promotes the production of prostaglandins in carrageenan-induced edema [55]. Hence, it is an effective strategy to suppress these cytokines for the management of different types of inflammatory disorders. In the present study, NOEE normalized the levels of TNF- $\alpha$, IL-1 $\beta$ and iNOS and their mRNA expressions in a dosedependent manner which were increased after carrageenan treatment in the rat paw. It is suggested that the anti-inflammatory activity of NOEE is also mediated by the inhibition of TNF- $\alpha$, IL- $1 \beta$ and iNOS mRNA expressions.

It has been reported that different types of acute inflammations result in the release of different inflammatory mediators in peritoneal fluids such as CRP, leukocytes COX-1, COX-2, 5-LO and 12-LO [56]. These chemicals sensitize and activate peripheral chemical mediated inflammatory responses. Basically, these types of responses generally occur due to the occurrence of peripheral inflammation [57]. The experimental extract showed a significant decrease in total leukocyte count and CRP levels at the dose of $500 \mathrm{mg} / \mathrm{kg}$. It seems that this reduction in CRP and leukocyte levels also provided us substantial evidence that NOEE has a significant potential to produce anti-inflammatory activity.

In the current research, we found that experimental extract having an inhibitory effect on both COX-1 and COX-2 enzymes in dose dependent manner. Interestingly, it was observed that extract showed a more potent inhibitory effect on COX-2 compared to COX-1 enzymes. The selective COX-2 inhibitors show therapeutic activity with few ulcers toxicity in GI tracts. A parallel relationship was suggested among COX-2 selectivity and NSAID treatment-related GI side effects since the COX2 selective compounds showed fewer ulcerative effects [58]. Similarly, lipoxygenase perform an imperative part in the pathophysiology of numerous inflammatory diseases [59]. Enzymes belong to the LOX group are 
responsible for catalyzing deoxygenation of polyunsaturated fatty acids. Present study results reflect the promising anti-LOX effects of NOEE; this might be due to the antioxidant potential of this plant.

In addition, no significant sign of toxicity was observed in Sprague Dawley rats after 14 days oral dosing of NOEE. A sub-acute toxicity study for 28 days was also performed to evaluate the toxic potential of plant extract. No significant changes were observed in body weights and relative organ weights of both genders at any dose of plant extract compared to control groups. All studied animals survived during the whole toxicity study until euthanasia was performed for further studies. No significant changes were observed in serum sodium, potassium and calcium levels and hematological parameters of studied animals after 28 days oral dosing of plant extract.

The biochemical analyses of blood serum are a widely used tool to assess the responses in living beings induced by different exogenous chemicals. The elevated levels indicate any damage or toxicity of body organs. After 28 days exposure to plant extract at three different doses, a significant increase was observed in hepatic enzymes and bilirubin levels at the dose of $2000 \mathrm{mg} / \mathrm{kg}$ in animals of both genders. This increased in enzymatic levels indicated the chances of hepatocellular injury at higher doses of plant extract. In cholestatic drug reactions, these types of enzymatic elevations along with hyperbilirubinemia are also observed [39]. However, this mild hepatotoxicity was observed at the dose of $2000 \mathrm{mg} / \mathrm{kg}$; which were about several times higher than the above defined effective concentrations for anti-inflammatory activity i.e. $100 \mathrm{mg} / \mathrm{kg}$. In addition, the normal levels of creatinine, BUN and uric acid at all doses indicated that plant extract did not produce any toxic effects on renal systems.

However, an extract of $N$. oleander used in our study was not much similar in its solvent properties as to the traditional approach where the population used aqueous extracts while we have used ethanolic extract due to the greater pharmacological activity reported in previous studies. In addition, it will be more beneficial to conduct in vivo human studies on $N$. oleander extract and should determine pharmacokinetic properties, adverse effects and serum-attainable levels.

\section{Conclusion}

In conclusion, this study demonstrated the significant dose-dependent anti-bacterial and anti-inflammatory activity of ethanolic flowers extract of $N$. oleander which could be exploited in the search for plant-based antiinflammatory agents. The extract involved in the bacterial cell membrane alterations for anti-bacterial activity. However, the anti-inflammatory activity of plant extract was observed through the reduction in the levels and
mRNA expressions of different pro-inflammatory mediators. In addition no toxicity was observed at therapeutics doses of plant extract in toxicity assay. Thus, the present study scientifically validated the traditional use of $\mathrm{N}$. oleander flowers for the treatment of elevated pain and inflammation, particularly in bacterial infections.

\begin{abstract}
Abbreviations
ALP: Alkaline phosphatase; AST: Aspartate transaminase; ALT: Alanine transaminase; BUN: Blood urea nitrogen; CRP: C-reactive protein;

COX: Cyclooxygenase; CLSI: Clinical Laboratory and Standard Institute; ESR: Erythrocyte sedimentation rate; HETE: Hydroxyeicosatetraenoic acid; IL1ß: Interleukin-1 $\beta$; LD: Lethal dose; LO: Lipoxygenase; MHA: Muller Hinton agar; MIC: Minimum inhibitory concentration; MBC: Minimum bactericidal concentration (MBC); NO: Nitric oxide; NOEE: Nerium oleander ethanolic extract; NSAIDs: Non-steroidal anti-inflammatory drugs; NIH: National Institute of Health; ODs: Optical densities; PCSIR: Pakistan Council of Scientific and Industrial Research; PGE 2: Prostaglandins-2; PI: Percent inhibitions; RBCs: Red blood cells; TSA: Tyramide Signal Amplification; TNF-a: Tumor necrosis factora; WHO: World health organization; WBCs: White blood cells
\end{abstract}

\section{Supplementary Information}

The online version contains supplementary material available at https://doi. org/10.1186/s12906-021-03308-z.

Additional file 1: Table S1. MIC and MBC of crude ethanolic flowers extract of $N$. oleander. Table S2. Body weight gain and relative organs weight of rats after treated with NOEE at different doses

\section{Acknowledgements \\ This research work was supported by Pakistan Council of Scientific and Industrial Research (PCSIR), Karachi-Pakistan.}

\section{Authors' contributions}

YS conducted the whole study under SBS and GHR supervision. M Arif Asghar and YS wrote the paper and help during the practical work, YS, MA, $A A, R B, S G$ and $M$ Asif Asghar were responsible for drafting and writing the final version of the manuscript. All authors performed data analysis in addition they read and approved the final manuscript.

\section{Funding}

The authors didn't received financial support from any institution.

Availability of data and materials

All data generated or analyzed during this study are included in this published article.

\section{Declarations}

\section{Ethics approval and consent to participate}

Animal handling was performed according to the guidelines of National Advisory Committee for Laboratory Animal Research (NACLAR). The written consent form was also filled by the animal house (DUHS) in-charge. Medetomidine was used as a sedating agent prior to the administration of T-61 solution as euthanizing agent [20]. Moreover, the study was approved by a local departmental animal ethical committee of Pakistan Council of Scientific and Industrial Research (PCSIR), Karachi-Pakistan with the approval number of 05/ 04/KK/PCSIR.

\section{Consent for publication \\ Not applicable.}

\section{Competing interests}

The authors declare that they have no competing interests.

\section{Author details}

'Department of Pharmaceutics, Institute of Pharmaceutical Sciences, Jinnah Sindh Medical University, Rafiqui H. J Shaheed Road, Karachi 75510, Pakistan. 
2Department of Pharmaceutics, Faculty of Pharmacy, Hamdard University, Karachi, Pakistan. ${ }^{3}$ Research Department, Faculty of Eastern Medicine, Hamdard University, Karachi, Pakistan. ${ }^{4}$ Department of Pharmaceutics, Dow College of Pharmacy, Dow University of Health Sciences, Karachi, Pakistan. ${ }^{5}$ Department of Pharmacology, Institute of Pharmaceutical Sciences, Jinnah Sindh Medical University, Karachi, Pakistan. ${ }^{6}$ Food and Feed Safety Laboratory, Food and Marine Resources Research Centre, PCSIR Laboratories Complex, Shahrah-e-Salimuzzaman Siddiqui, Off University Road, 74200, Karachi, Sindh 75280, Pakistan.

Received: 11 June 2020 Accepted: 21 April 2021 Published online: 01 May 2021

\section{References}

1. Sala A, Proschak E, Steinhilber D, Rovati GE. Two-pronged approach to antiinflammatory therapy through the modulation of the arachidonic acid cascade. Biochem Pharmacol. 2018;158:161-73. https://doi.org/10.1016/j. bcp.2018.10.007.

2. Danese A, Baldwin JR. Hidden wounds? Inflammatory links between childhood trauma and psychopathology. Annu Rev Psychol. 2017;68(1):51744. https://doi.org/10.1146/annurev-psych-010416-044208.

3. Oshima N, Shimizu T, Narukawa Y, Hada N, Kiuchi F. Quantitative analysis of the anti-inflammatory activity of orengedokuto $\|$ : berberine is responsible for the inhibition of NO production. J Nat Med. 2018;72(3):706-14. https:// doi.org/10.1007/s11418-018-1209-7.

4. Rodríguez-Hernández H, Simental-Mendía LE, Rodríguez-Ramírez G, ReyesRomero MA. Obesity and inflammation: epidemiology, risk factors, and markers of inflammation. Int J Endocrinol. 2013:1-11. https://doi.org/10.11 55/2013/678159.

5. Wongrakpanich S, Wongrakpanich A, Melhado K, Rangaswami J. A comprehensive review of non-steroidal anti-inflammatory drug use in the elderly. Aging Dis. 2018;9(1):143-50. https://doi.org/10.14336/AD.2017.0306

6. Rehman AA, Riaz A, Asghar MA, Raza ML, Ahmed S, Khan K. In vivo assessment of anticoagulant and antiplatelet effects of Syzygium cumini leaves extract in rabbits. BMC Complement Altern Med. 2019;19:1-8.

7. Ullah I, Khan JA, Shahid M, Khan A, Adhikari A, Hannan PA, et al. Pharmacological screening of Monotheca buxifolia (Falc.) a. DC. For antinociceptive, anti-inflammatory and antipyretic activities. BMC Complement Altern Med. 2016;16:1-8.

8. Naz R, Ayub H, Nawaz S, Islam ZU, Yasmin T, Bano A, et al. Antimicrobial activity, toxicity and anti-inflammatory potential of methanolic extracts of four ethnomedicinal plant species from Punjab, Pakistan. BMC Complement Altern Med. 2017;17:1-13.

9. Shafiq Y, Naqvi SBS, Rizwani GH, Abbas T, Sharif H, Ali H, et al. Assessment of killing kinetics assay and bactericidal mechanism of crude methanolic bark extract of Casuarina equisetifolia. Pak J Pharm Sci. 2018;31(5):2143-8.

10. Joshee N, Dhekney SA, Parajuli P: Medicinal plants: from farm to pharmacy: springer nature; 2019, DOl: https://doi.org/10.1007/978-3-030-31269-5.

11. Bandara V, Weinstein SA, White J, Eddleston M. A review of the natural history, toxinology, diagnosis and clinical management of Nerium oleander (common oleander) and Thevetia peruviana (yellow oleander) poisoning. Toxicon. 2010;56(3):273-81. https://doi.org/10.1016/j.toxicon.2010.03.026.

12. El Sawi NM, Geweely NS, Qusti S, Mohamed M, Kamel A. Cytotoxicity and antimicrobial activity of Nerium oleander extracts. J Appl Anim Res. 2010; 37(1):25-31. https://doi.org/10.1080/09712119.2010.9707089.

13. Hadizadeh I, Peivastegan B, Kolahi M. Antifungal activity of nettle (Urtica dioica L.), colocynth (Citrullus colocynthis L. Schrad), oleander (Nerium oleander L.) and konar (Ziziphus spina-christi L.) extracts on plants pathogenic fungi. Pak J Biol Sci. 2009;12(1):58-63. https://doi.org/10.3923/ pjbs.2009.58.63.

14. Dey P, Saha MR, Chowdhuri SR, Sen A, Sarkar MP, Haldar B, et al. Assessment of anti-diabetic activity of an ethnopharmacological plant Nerium oleander through alloxan induced diabetes in mice. J Ethnopharmacol. 2015;161:128-37. https://doi.org/10.1016/j.jep.2014.12.012.

15. Singhal KG, Gupta GD. Hepatoprotective and antioxidant activity of methanolic extract of flowers of Nerium oleander against CCl4-induced liver injury in rats. Asian Pac J Trop Med. 2012;5(9):677-85. https://doi.org/1 0.1016/S1995-7645(12)60106-0.

16. Rashan L, Franke K, Khine MM, Kelter G, Fiebig HH, Neumann J, et al. Characterization of the anticancer properties of monoglycosidic cardenolides isolated from Nerium oleander and Streptocaulon tomentosum. J Ethnopharmacol. 2011;134(3):781-8. https://doi.org/10.1016/ j.jep.2011.01.038

17. Govind P. Protective effect of Nerium indicum on ccl4 induced hepatotoxicity in rat. Int J Biomed Res. 2010;1(4):147-52.

18. Derwich E, Benziane Z, Boukir A. Antibacterial activity and chemical composition of the essential oil from flowers of Nerium oleander. Electron J Environ Agricult Food Chemist. 2010;9(6):1074-1084.

19. Ibrahim AM, Ghareeb MA. Preliminary phytochemical screening, total phenolic content, in vitro antioxidant and molluscicidal activities of the methanolic extract of five medicinal plants on Biomphalaria alexandrina snails. J Herbs Spices Med Plants. 2020;26(1):40-8.

20. Torres-Rêgo M, Furtado AA, Bitencourt MAO, de Souza Lima MCJ, de Andrade RCLC, de Azevedo EP, et al. Anti-inflammatory activity of aqueous extract and bioactive compounds identified from the fruits of Hancornia speciosa Gomes (Apocynaceae). BMC Complement Altern Med. 2016;16:1-10.

21. Saleem TM, Azeem A, Dilip C, Sankar C, Prasanth N, Duraisami R. Antiinflammatory activity of the leaf extacts of Gendarussa vulgaris Nees. Asian Pac J Trop Biomed. 2011;1(2):147-9. https://doi.org/10.1016/S2221-1691(11)60014-2.

22. Mumtaz N, Naqvi SBS, Asghar MA, Asghar MA. Assessment of antimicrobial activity of Sphaeranthus indicus L. against highly resistant pathogens and its comparison with three different antibiotics. J Dis Glob Health. 2017;10:67-73.

23. Hsueh P-R, Ko W-C, Wu J-J, Lu J-J, Wang F-D, Wu H-Y, et al. Consensus statement on the adherence to clinical and laboratory standards institute (CLSI) antimicrobial susceptibility testing guidelines (CLSI-2010 and CLSI2010-update) for Enterobacteriaceae in clinical microbiology laboratories in Taiwan. J Microbiol Immunol Infect. 2010;43(5):452-5. https://doi.org/10.101 6/S1684-1182(10)60070-9.

24. Shafiq $Y$, Asghar MA, Ali H, Abedin S, Rehman AA, Anser H. In vitro assessment of antimicrobial potential of Ethanolic and aqueous extract of Phlomis Umbrosa against some highly resistant pathogens. Ann Jinnah Sindh Med Univ. 2020;6(1):3-9. https://doi.org/10.46663/ajsmu.v6i1.3-9.

25. Asghar MA, Zahir E, Shahid SM, Khan MN, Asghar MA, lqbal J, et al. Iron, copper and silver nanoparticles: green synthesis using green and black tea leaves extracts and evaluation of antibacterial, antifungal and aflatoxin B1 adsorption activity. Lwt. 2018;90:98-107. https://doi.org/10.1 016/j.lwt.2017.12.009.

26. Asghar MA, Zahir E, Asghar MA, lqbal J, Rehman AA. Facile, one-pot biosynthesis and characterization of iron, copper and silver nanoparticles using Syzygium cumini leaf extract: as an effective antimicrobial and aflatoxin B1 adsorption agents. PLoS One. 2020;15(7):e0234964. https://doi. org/10.1371/journal.pone.0234964.

27. Khawaja H, Zahir E, Asghar MA, Asghar MA. Graphene oxide, chitosan and silver nanocomposite as a highly effective antibacterial agent against pathogenic strains. Colloids Surf A Physicochem Eng Asp. 2018;555:246-55. https://doi.org/10.1016/j.colsurfa.2018.06.052

28. Mumtaz N, Asghar MA, Naqvi SBS, Asghar MA, Raza ML, Rehman AA. Time kill assay and bactericidal mechanism of action of ethanolic flowers extract of Sphaeranthus indicus. RADS J Pharm Pharmaceut Sci. 2019;7(1):27-33.

29. Asghar MA, Asghar MA. Green synthesized and characterized copper nanoparticles using various new plants extracts aggravate microbial cell membrane damage after interaction with lipopolysaccharide. Int J Biol Macromol. 2020;160:1168-76. https://doi.org/10.1016/j.jibiomac.2020.05.198.

30. Asghar MA, Yousuf RI, Shoaib MH, Asghar MA. Antibacterial, anticoagulant and cytotoxic evaluation of biocompatible nanocomposite of chitosan loaded green synthesized bioinspired silver nanoparticles. Int J Biol Macromol. 2020;160:934-43. https://doi.org/10.1016/j.jjbiomac.2020.05.197.

31. Rai U, Rawal A, Singh S. Evaluation of the anti-inflammatory effect of an anti-platelet agent crinumin on carrageenan-induced paw oedema and granuloma tissue formation in rats. Inflammopharmacology. 2018;26(3):76978. https://doi.org/10.1007/s10787-017-0411-7.

32. Yuan A, Gong L, Luo L, Dang J, Gong X, Zhao M, et al. Revealing antiinflammation mechanism of water-extract and oil of forsythiae fructus on carrageenan-induced edema rats by serum metabolomics. Biomed Pharmacother. 2017;95:929-37. https://doi.org/10.1016/j.biopha.2017.09.009.

33. Li Y-C, Xian Y-F, Ip S-P, Su Z-R, Su J-Y, He J-J, et al. Anti-inflammatory activity of patchouli alcohol isolated from Pogostemonis Herba in animal models. Fitoterapia. 2011;82(8):1295-301. https://doi.org/10.1016/j.fitote.2011.09.003.

34. Hu X-D, Yang $Y$, Zhong X-G, Zhang X-H, Zhang Y-N, Zheng Z-P, et al. Antiinflammatory effects of Z23 on LPS-induced inflammatory responses in RAW264. 7 macrophages. J Ethnopharmacol. 2008;120(3):447-51. https://doi. org/10.1016/j.jep.2008.09.026. 
35. Livak KJ, Schmittgen TD. Analysis of relative gene expression data using real-time quantitative $P C R$ and the $2-\Delta \Delta C T$ method. Methods. 2001; 25(4):402-8.

36. Hijazi MA, El-Mallah A, Aboul-Ela M, Ellakany A: Evaluation of analgesic activity of Papaver libanoticum extract in mice: involvement of opioids receptors Evidence-Based Complementary and Alternative Medicine 2017, 2017

37. Li RW, Lin GD, Myers SP, Leach DN. Anti-inflammatory activity of Chinese medicinal vine plants. J Ethnopharmacol. 2003;85(1):61-7. https://doi.org/1 0.1016/S0378-8741(02)00339-2.

38. Oecd: OECD Guidelines for the Testing of Chemicals: Organization for Economic; 1994

39. Asghar MA, Yousuf Rl, Shoaib MH, Asghar MA, Ansar S, Zehravi M, et al. Synergistic Nanocomposites of different antibiotics coupled with green synthesized chitosan-based silver nanoparticles: characterization, antibacterial, in vivo toxicological and biodistribution studies. Int J Nanomedicine. 2020;15:7841-59. https://doi.org/10.2147/IJN.S274987.

40. Raafat D, Leib N, Wilmes M, François P, Schrenzel J, Sahl H-G. Development of in vitro resistance to chitosan is related to changes in cell envelope structure of Staphylococcus aureus. Carbohydr Polym. 2017;157:146-55. https://doi.org/10.1016/j.carbpol.2016.09.075

41. Namian P, Talebi T, Germi KG, Shabani F. Screening of biological activities (antioxidant, antibacterial and antitumor) of Nerium oleander leaf and flower extracts. Vacuum. 2013;10(11):378-384.

42. Manivannan K, Anantharaman P, Balasubramanian T. Antimicrobial potential of selected brown seaweeds from Vedalai coastal waters, gulf of Mannar. Asian Pac J Trop Biomed. 2011;1(2):114-20. https://doi.org/10.1016/S2221-1 691(11)60007-5.

43. Dholvitayakhun A, Trachoo N, Narkkong N-A, Cushnie TT. Using scanning and transmission electron microscopy to investigate the antibacterial mechanism of action of the medicinal plant Annona squamosa Linn. J Herb Med. 2017:7:31-6. https://doi.org/10.1016/j.hermed.2016.10.003.

44. Limsuwan S, Moosigapong K, Jarukitsakul S, Joycharat N, Chusri S, Jaisamut $P$, et al. Lupinifolin from Albizia myriophylla wood: a study on its antibacterial mechanisms against cariogenic Streptococcus mutans. Arch Oral Biol. 2018:93:195-202. https://doi.org/10.1016/j.archoralbio.2017.10.013.

45. Pacheco SM, Azambuja JH, de Carvalho TR, Soares MSP, Oliveira PS, da Silveira EF, et al. Glioprotective effects of lingonberry extract against altered cellular viability, acetylcholinesterase activity, and oxidative stress in lipopolysaccharide-treated astrocytes. Cell Mol Neurobiol. 2018;38(5): 1107-21. https://doi.org/10.1007/s10571-018-0581-x.

46. Erdemoglu N, Küpeli E, Yeşilada E. Anti-inflammatory and antinociceptive activity assessment of plants used as remedy in Turkish folk medicine. J Ethnopharmacol. 2003;89(1):123-9. https://doi.org/10.101 6/S0378-8741(03)00282-4.

47. Botting J. Defining the role of COX-2 inhibitors in inflammatory and other diseases. Drug News Perspect. 2000;13(9):560-6. https://doi.org/10.1358/ dnp.2000.13.9.660938.

48. Minghetti L. Cyclooxygenase-2 (COX-2) in inflammatory and degenerative brain diseases. J Neuropathol Exp Neurol. 2004;63(9):901-10. https://doi. org/10.1093/jnen/63.9.901.

49. Dinarello CA. Proinflammatory and anti-inflammatory cytokines as mediators in the pathogenesis of septic shock. Chest. 1997;112(6):321S-9S. https://doi. org/10.1378/chest.112.6_Supplement.321S.

50. Lubberts $E$, van den Berg WB: Cytokines in the pathogenesis of rheumatoid arthritis and collagen-induced arthritis. Madame Curie Bioscience Database [Internet] 2013.

51. Dinarello CA. Proinflammatory cytokines. Chest. 2000;118(2):503-8. https:// doi.org/10.1378/chest.118.2.503.

52. Loram L, Fuller A, Fick L, Cartmell T, Poole S, Mitchell D. Cytokine profiles during carrageenan-induced inflammatory hyperalgesia in rat muscle and hind paw. J Pain. 2007;8(2):127-36. https://doi.org/10.1016/j.jpain.2006.06.010.

53. Toriyabe M, Omote K, Kawamata T, Namiki A. Contribution of interaction between nitric oxide and cyclooxygenases to the production of prostaglandins in carrageenan-induced inflammation. J Am Soc Anesthesiol. 2004;101(4):983-90.

54. Sakaguchi Y, Shirahase H, Kunishiro K, Ichikawa A, Kanda M, Uehara Y. Effect of combination of nitric oxide synthase and cyclooxygenase inhibitors on carrageenan-induced pleurisy in rats. Life Sci. 2006;79(5):442-7. https://doi. org/10.1016/j.lfs.2006.01.022.
55. Salvemini D, Wang ZQ, Wyatt PS, Bourdon DM, Marino MH, Manning PT, et al. Nitric oxide: a key mediator in the early and late phase of carrageenan-induced rat paw inflammation. Br J Pharmacol. 1996;118(4): 829-38. https://doi.org/10.1111/j.1476-5381.1996.tb15475.x.

56. Chun JM, Lee AR, Kim HS, Lee AY, Gu GJ, Moon BC, et al. Peucedanum japonicum extract attenuates allergic airway inflammation by inhibiting Th2 cell activation and production of pro-inflammatory mediators. $J$ Ethnopharmacol. 2018;211:78-88. https://doi.org/10.1016/j.jep.2017.09.006.

57. Yam MF, Loh YC, Tan CS, Khadijah Adam S, Abdul Manan N, Basir R. General pathways of pain sensation and the major neurotransmitters involved in pain regulation. Int J Mol Sci. 2018;19(8):2164. https://doi.org/10.3390/ijms1 9082164.

58. Bazan N, Botting JH, Vane JR: New targets in inflammation: inhibitors of COX-2 or adhesion molecules proceedings of a conference held on April 15-16, 1996, in New Orleans, USA, supported by an educational grant from Boehringer Ingelheim: Springer Science \& Business Media; 2012.

59. Wedi B, Kapp A. Pathophysiological role of leukotrienes in dermatological diseases. BioDrugs. 2001;15(11):729-43. https://doi.org/10.2165/00063030-2 00115110-00004.

\section{Publisher's Note}

Springer Nature remains neutral with regard to jurisdictional claims in published maps and institutional affiliations.
Ready to submit your research? Choose BMC and benefit from:

- fast, convenient online submission

- thorough peer review by experienced researchers in your field

- rapid publication on acceptance

- support for research data, including large and complex data types

- gold Open Access which fosters wider collaboration and increased citations

- maximum visibility for your research: over $100 \mathrm{M}$ website views per year

At $\mathrm{BMC}$, research is always in progress.

Learn more biomedcentral.com/submissions 